\title{
Benzopyran-Core as an Antimycobacterial Agent
}

\author{
Sandile B Simelane ${ }^{1 *}$, Paseka T Moshapo ${ }^{2}$ and Raban W Masuka ${ }^{3}$ \\ ${ }^{1}$ Department of Chemistry, Faculty of Science and Engineering, University of Eswatini, Eswatini \\ ${ }^{2}$ Department of Chemical Sciences, University of Johannesburg, South Africa \\ ${ }^{3}$ University of Zimbabwe, School of Pharmacy, Mt Pleasant Drive, Zimbabwe
}

Submission: October 18, 2020; Published: December 01, 2020

"Corresponding author: Sandile B Simelane, Department of Chemistry, Faculty of Science and Engineering, University of Swaziland, Private Bag 4, Kwaluseni, Swaziland

\section{Abstract}

Tuberculosis (TB) is one of the world's most deadly infectious diseases, causing 1.2 million deaths in 2018 . TB is the leading cause of death from a single infectious agent, ahead of HIV/AIDS. The African continent bears the highest global TB/HIV burden and over 50\% of TB cases in sub-Saharan Africa are co-infected with HIV. With an estimated 1.7 billion people (23\% of the world's population) with latent TB infection, there is an urgent need to develop drugs that will eradicate or control the disease. Moreover, the emergence of multi-drug resistant tuberculosis (MDR-TB) and extensively drug resistant tuberculosis (XDR-TB) have accelerated the need for new antitubercular agents with novel biological targets and different mechanism of action. Among the wide spectra of heterocyclic compounds, benzopyran derivatives have displayed diverse biological applications. Found in many natural products, this scaffold together with its synthetic analogs has intrigued medicinal chemists to explore its applicability as anti-TB drugs. To further intensify research in this area, there is need to gather the latest information on benzopyrans as antimycobacterial agents. This review presents an overview of recent developments (2000 -2018) in anti-TB applications of benzopyrans, both the synthetic analogs and isolated natural products. The objective of this review is to focus on active benzopyran analogs and structure activity relationship (SAR) analysis. We envisage that this review will be helpful in rational design of potent, less toxic benzopyran-based anti-TB drug candidates.

Keywords: Mycobacterium tuberculosis; Anti-TB agents; Medicinal chemistry; Benzopyran

Abbreviations

TB: Tuberculosis; HIV/AIDS: Human immunodeficiency virus infection/acquired immune deficiency syndrome; MDR-TB: multi-drug resistant tuberculosis; XDR-TB: extensively drug resistant tuberculosis; SAR: structure activity relationship; Mtb: Mycobacterium tuberculosis; INH: isoniazid; RIF: rifampicin; ETB: ethambutol; PZA: pyrazinamide; SADC: Southern African Development Community; CYP1B1: Cytochrome P450 Family 1 Subfamily B Member 1; MIC: minimum inhibitory concentration; FtsZ: filament temperature-sensitive mutantZ; MABA: micro-plate alamar blue assay; SI: selectivity index; sm-DNA: salmon milt-Deoxyribonucleic acid; A-T: adeninethiamide; MmpL3: Mycobacterial membrane protein Large; BCG: Bacillus Calmette-Guérin; MRA: microdilution resazurin assay; L-J: Lowenstein-Jensen; DprE1: decaprenylphosphoryl$\beta$-D-ribose 2'-epimerase; TAACF: tuberculosis antimicrobial acquisition and coordinating facility; ATP: Adenosine triphosphate; HadAB: $\beta$-hydroxyacyl-ACP dehydratase

\section{Introduction}

Tuberculosis (TB) is a chronic and potentially fatal disease caused by Mycobacterium tuberculosis (Mtb) complex. The Mtb complex is made up of bacilli from M. tuberculosis, M. bovis, M. mungi, M. caprae, M. canettii, M. africanum, M. microti and M. pinnipedii [1-3]. Known as "white plague", Mtb was first isolated and identified by Robert Koch in 1882 [4]. In 2017, TB caused an estimated 1.3 million deaths among HIV-negative people and there were an additional 300000 deaths from TB among HIV-positive people [5]. One-third of the world's population is affected with $M t b$ and an estimated 10 million people developed TB in 2017, with 488000 of them affected by multi drug-resistant TB (MDRTB). Multi drug-resistant TB is defined as tuberculosis whose bacteria are resistant to isoniazid (INH) and rifampicin (RIF). If the bacterium is resistant to isoniazid and rifampicin as well as any of the floroquinolones, it is called extensively drug resistant TB (XDR-TB) [6]. 
The standard first line therapy for the treatment of active TB is a cocktail of rifampicin (RIF), isoniazid (INH), ethambutol (ETB) and pyrazinamide (PZA). After two months the number of drugs is reduced to rifampicin and isoniazid for four months, (2HRZE/4HR) [7]. Treatment of MDR-TB is longer and requires more toxic drugs [8]. MDR-TB is treated by a combination of eight to ten drugs with therapies lasting up to 18-24 months. Extensively drug resistant TB (XDR-TB) is virtually untreatable [9]. Tuberculosis is a transmissible infection, and Mtb is mainly transmitted by airborne aerosols through coughing, sneezing, speaking or any other respiratory fluids in the air from people with active pulmonary TB [10]. Mtb typically affects the lungs, but it can also affect other parts of the body and it is known as extrapulmonary tuberculosis. Common extrapulmonary sites of infection include lymph nodes, pleura and osteoarticular areas [11]. Extrapulmonary TB is common in people with a weakened immune system like those with HIV co-infections [12]. In some cases, the infection causes no symptoms, and it is called latent TB.

The World Health Organization [13] once estimated that 1 billion new cases of $M t b$ infections will be reported in the next two decades. They also reported that in $2017,87 \%$ of new TB cases occurred in the 30 high TB burden countries [5]. Amongst these 30 countries, 16 (53\%) are African countries and 9 of those are in the Southern African Development Community (SADC) [14]. These statistics should stimulate medicinal chemists and pharmacologists to invent new drug candidates with novel mechanism of action to combat or control the spread of $M t b$. Some of the review articles found in literature in this research area range from target identification studies, distinct class of molecules as well as clinical status of different types of anti-TB compounds, some of which are heterocyclic compounds [15-19].

Heterocycle-based organic derivatives offer potential for the design of new drug-like molecules. These molecules have had a profound impact on both chemical biology and drug discovery [20]. Among these heterocycles, one that has received considerable attention from medicinal chemists is the benzopyran structural motif [21]. Benzopyrans are polycyclic molecules in which a benzene ring and pyran ring are fused together with various levels of saturation [22]. The name benzopyran is widely used to refer to polycycles fused with a pyran ring (chromenes), but also applies to heterocycles bearing a dihydropyran (chromans) and some of the benzopyran skeletons are shown in Figure 1.
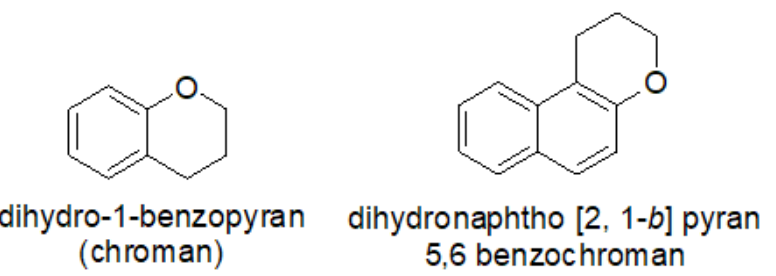

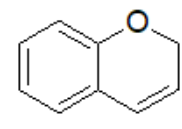

2H-1-benzopyran (2H-chromene)<smiles>C1=COc2ccccc2C1</smiles>

4H-1-benzopyran (4H-chromene)

Figure 1: Structural skeletons of 1-benzopyrans.

Nicolaou et al. [23] labelled the benzopyran scaffold as a privileged structure because it is found in a range of biologically active compounds, both synthetic and naturally occurring. The benzopyran structural motif plays an important role in numerous pharmaceutical molecules with a wide range of biological properties, which include anti-cancer [24], anti-inflammatory [25], antibacterial [26], anti-arthritis [27], anti-viral [28], anti-Alzheimer's [29], anti-skin disease activities [30] and the treatment of type 2 diabetes [31]. In addition some benzopyran derivatives have demonstrated potential as alanine racemase inhibitors [32], cytochrome P450 1B1 (CYP1B1) inhibitors [33], monocarboxylate transporter 1 inhibitors [34], P-glycoprotein inhibitors [35] and $\alpha$-glucosaminidase inhibitors [36]. Some benzopyran derived commercial drugs include warfarin (for treatment of retinal occlusion, pulmonary embolism, and cerebral embolism), flavoxate (for symptomatic relief of dysuria), dronabinol (for stimulating appetite), nebivolol (for treatment of essential hypertension) and vitamin E which is an antioxidant with demonstrated immune enhancing effects (Figure 2).
Xiu et al. [21] recently reviewed the therapeutic applications of benzopyrans. However, there is no review article that has detailed the significance of this scaffold as anti-TB agents. Benzopyrans with a carbonyl or phenyl group at position 2 are coumarins and flavonoids, respectively. Coumarins and flavonoids have been reviewed as antimycobacterial agents $[37,38]$, hence are not part of this review. In the present article we focus on published reports (from 2000-2018) of benzopyran derivatives as potential anti-TB agents.

\section{Synthetic anti-TB benzopyran derivatives}

Raju et al. [39] synthesized a series of 4H-chromen-1,2,3,4tetrahydropyrimidine-5-carboxylate derivatives and screened for their in vitro antimycobacterial activity against $M t b \mathrm{H}_{37} \mathrm{Rv}$, using the agar dilution method [40]. The results showed that six compounds 1 (a-d), 2 and 3 exhibit excellent activity with minimum inhibitory concentration (MIC) values between 3.4$7.4 \mu \mathrm{M}$ and were more potent than standard drugs ethambutol $(\mathrm{MIC}=7.6 \mu \mathrm{M})$ and ciprofloxacin $(\mathrm{MIC}=9.5 \mu \mathrm{M})$ (Figure 3). The 
electron withdrawing trifluoromethyl group at the 6th position of the 1,2,3,4-tetrahydropyrimidine-5-carboxylates enhances antimycobacterial activity better than methyl and phenyl substituents. Nitro substitution on the phenyl ring also play an important role in enhancing the activity compared to halides. Also, the furan ring fused to the phenyl moiety of the chromone 2 and 3 maintained potency of the 4 H-chromen-1,2,3,4tetrahydropyrimidine-5-carboxylate derivatives.

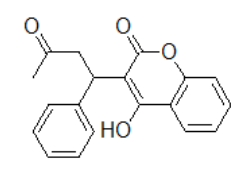

Warfarin

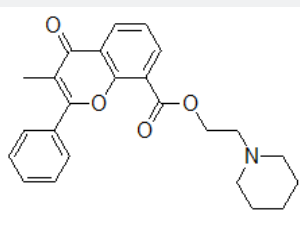

Flavox ate

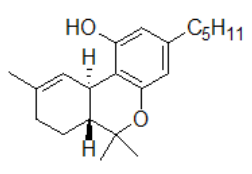

Dronabinol
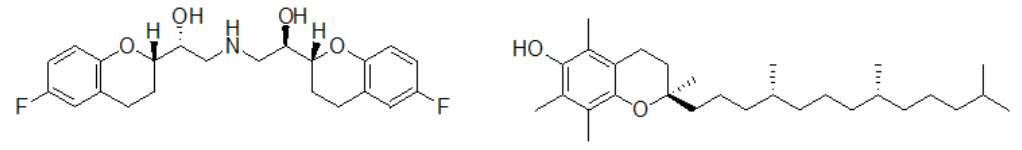

Nebivolol

Vitam in E

Figure 2: Commercial drugs with benzopyran nucleus.

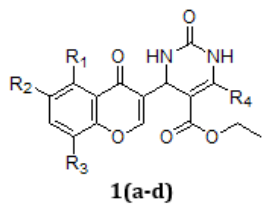

a) $\mathrm{R}_{1}=\mathrm{H}, \mathrm{R}_{2}=\mathrm{Ph}, \mathrm{R}_{3}=\mathrm{H}, \mathrm{R}_{4}=\mathrm{CF}_{3} ; \mathrm{MIC}\left(\mathrm{Mtb} \mathrm{H}_{3} \mathrm{Rv}\right)=3.4 \mu \mathrm{M}$

b) $\mathrm{R}_{1}=\mathrm{CH}_{3}, \mathrm{R}_{2}=\mathrm{H}, \mathrm{R}_{3}=\mathrm{H}, \mathrm{R}_{4}=\mathrm{CF}_{3}$; $\mathrm{MIC}\left(M t b \mathrm{H}_{3} 7 \mathrm{Rv}\right)=3.9 \mu \mathrm{M}$

c) $\mathrm{R}_{1}=\mathrm{H}, \mathrm{R}_{2}=\mathrm{NO}_{2}, \mathrm{R}_{3}=\mathrm{H}, \mathrm{R}_{4}=\mathrm{CH}_{3} ; \mathrm{MIC}\left(M t b \mathrm{H}_{37} \mathrm{Rv}\right)=4.2 \mu \mathrm{M}$

d) $\mathrm{R}_{1}=\mathrm{H}, \mathrm{R}_{2}=\mathrm{H}, \mathrm{R}_{3}=\mathrm{NO}_{2}, \mathrm{R}_{4}=\mathrm{CH}_{3} ; \mathrm{MIC}\left(M t b \mathrm{H}_{3} 7 \mathrm{Rv}\right)=4.2 \mu \mathrm{M}$

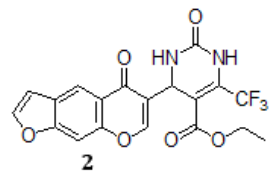

$\operatorname{MIC}\left(M t b \mathrm{H}_{37} \mathrm{Rv}\right)=7.4 \mu \mathrm{M}$

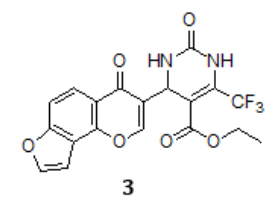

$\operatorname{MIC}\left(M t b \mathrm{H}_{37} \mathrm{Rv}\right)=3.7 \mu \mathrm{M}$

Figure 3: 4H-chromen-1,2,3,4-tetrahydropyrimidine-5-carboxylate compounds.

Amino alcohol fused spirochromone conjugates were prepared and evaluated for their potential anti-TB application against $M t b \mathrm{H}_{37} \mathrm{Rv}$. Compound (4a) was found to be the most active compound with $\mathrm{MIC}=3.13 \mu \mathrm{g} / \mathrm{mL}$ (Figure 4). The structure activity relationship of the amino alcohol fused spirochromone conjugates revealed that compounds possessing cycloalkyl and more specifically cyclopentyl group at the 2nd position of the chromanone ring favor better activity than a piperidinyl moiety. Furthermore, the isopropyl group on the aromatic ring of the amino alcohol as well as halide substitution enhances activity [41]. Dongamanti et al. [42] reported synthesis of chemically modified bis-spirochromanones starting from 2-hydroxyacetophenone and 1,4-dioxaspiro [4.5] decan-8-one using the Kabbe condensation method [43].
The bis-spirochromanones were evaluated for their potential in vitro antimycobacterial activity against $\mathrm{H}_{37} \mathrm{Rv}$ strain using the agar dilution method to determine minimum inhibitory concentration (MIC) values. Compounds 5 and 6 with MIC values of 5.30 and $6.40 \mu \mathrm{M}$ respectively, were found to be more potent than the first line antitubercular drug ethambutol $(\mathrm{MIC}=7.64 \mu \mathrm{M})$ (Figure 4). Furthermore, the bis-spirochromanones e.g. compound 5 were found to be more potent than mono-spirochromanones and compound 6 with three chroman-4-one pharmacophores was amongst the most potent bulky molecules. This was further supported by docking studies into the filament temperaturesensitive mutant $\mathrm{Z}$ (FtsZ) domain of $M t b \mathrm{H}_{37}$ Rv. Compounds with a higher surface area in the active site also exhibited higher docking scores. For compound 6 , the docking score and surface area were $-6.52 \mathrm{Kcal} / \mathrm{mol}$ and $408 \AA^{2}$ respectively. 


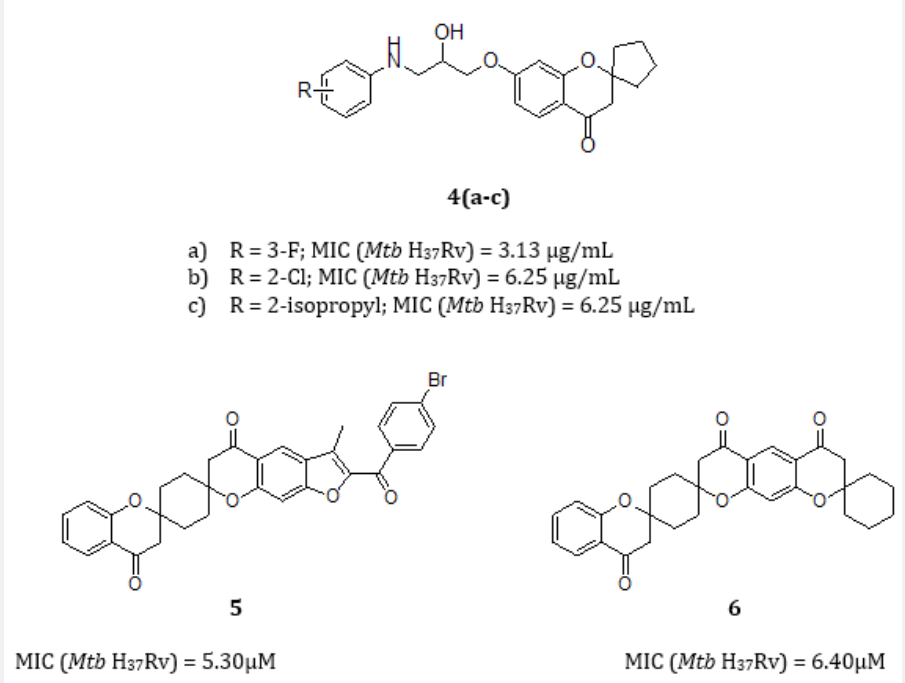

Figure 4: Structures of amino alcohol fused spirochromanone and bis-spirochromanone compounds.

Singh et al. [44] described the synthesis of 3-furanochromones and assessed their antitubercular activity against the $\mathrm{H}_{37} \mathrm{Rv}$ strain of $M t b$. The MIC values of the compounds were determined using the micro-plate alamar blue assay (MABA) [45]. The compounds 7(a-d) showed moderate antitubercular activity with MIC values ranging between 10 and $12 \mu \mathrm{g} / \mathrm{mL}$ (Figure 5). Das et al. [46] reported the synthesis of 3-benzylidine4-chromanones and evaluated them for growth inhibition of $M t b$ $\mathrm{H}_{37} \mathrm{Rv}$ in BACTEC 12B medium and the growth inhibition was determined by the broth dilution assay [47]. Compound (8a) with a meta-bromo substituent on the benzylidine moiety showed highest inhibition (99\%) at a concentration of $10 \mu \mathrm{g} / \mathrm{mL}$ (Figure 5). The $\mathrm{IC}_{50}$ and $\mathrm{IC}_{90}$ values of compounds with greater than $90 \%$ inhibition were generated using the microplate alamar blue assay. All these compounds $8(\mathrm{a}-\mathrm{c})$ showed $\mathrm{IC}_{50}$ and $\mathrm{IC}_{90}$ values less than $1 \mu \mathrm{g} / \mathrm{mL}$ with a selectivity index (SI) greater than 20 . Meta-substituted 3-benzylidine-4-chromanone derivatives were more potent than their ortho- and para-substituted counterparts. Furthermore, the 3-benzylidine-4-chromanones were more active than 2-benzylidine cyclohexanones, confirming the importance of the oxygen for activity.

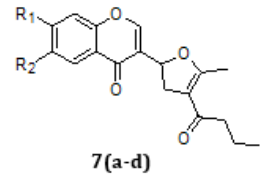

a) $\mathrm{R}_{1}=\mathrm{H}_{1} \mathrm{R}_{2}=\mathrm{H} ; \mathrm{MIC}\left(\mathrm{Mtb} \mathrm{H}_{3} 7 \mathrm{Rv}\right)=10 \mu \mathrm{g} / \mathrm{mL}$

b) $\mathrm{R}_{1}=\mathrm{H}_{1} \mathrm{R}_{2}=\mathrm{OMe} ; \mathrm{MIC}\left(\right.$ Mtb $\left.\mathrm{H}_{3} \mathrm{Rv}\right)=12 \mu \mathrm{g} / \mathrm{m}$

c) $\mathrm{R}_{1}=\mathrm{OMe}, \mathrm{R}_{2}=\mathrm{H} ; \mathrm{MIC}\left(\mathrm{Mtb}_{3} \mathrm{H} \mathrm{Rv}\right)=10 \mu \mathrm{g} / \mathrm{mL}$

d) $\mathrm{R}_{1}=\mathrm{OEt}, \mathrm{R}_{2}=\mathrm{H} ; \mathrm{MIC}\left(\mathrm{Mtb} \mathrm{H}_{37} \mathrm{Rv}\right)=10 \mu \mathrm{g} / \mathrm{mL}$

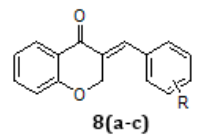

a) $\mathrm{R}=3-\mathrm{Br} ; \mathrm{IC}_{50}\left(\mathrm{Mtb}_{3} \mathrm{H}_{3} \mathrm{Rv}\right)=0.56 \mu \mathrm{g} / \mathrm{mL}$ IC $90\left(M t b \mathrm{H}_{37} \mathrm{Rv}\right)=0.77 \mu \mathrm{g} / \mathrm{mL}$ $\%$ inhibition $(10 \mu \mathrm{g} / \mathrm{mL})=99$

b) $\mathrm{R}=3-\mathrm{OCH}_{3} ; \mathrm{IC}_{50}\left(\mathrm{Mtb} \mathrm{H}_{3} \mathrm{Rv}\right)=<0.20 \mu \mathrm{g} / \mathrm{mL}$ $\mathrm{IC}_{90}\left(\mathrm{Mtb} \mathrm{H}_{3} \mathrm{Rv}\right)=<0.20 \mu \mathrm{g} / \mathrm{mL}$
$\%$ inhibition $(10 \mu \mathrm{g} / \mathrm{mL})=98$

c) $\mathrm{R}=3-\mathrm{CH}_{3} ; \mathrm{IC}_{50}\left(M t b \mathrm{H}_{3} \mathrm{Rv}\right)=0.46 \mu \mathrm{g} / \mathrm{mL}$ $\mathrm{IC} \mathrm{C}_{90}\left(\mathrm{Mtb} \mathrm{H}_{3} \mathrm{Rv}\right)=0.72 \mu \mathrm{g} / \mathrm{mL}$ $\%$ inhibition $(10 \mu \mathrm{g} / \mathrm{mL})=90$

Figure 5: Structures of 3-furano-chromones, 3-benzylidine-4-chromanones and chromanol compounds. 
Feng et al. [48] synthesized a series of chemically modified 4-chromanones and evaluated them against $M t b \mathrm{H}_{37} \mathrm{Rv}$. The 2-propyl-4-chromanol 9 showed better activity in the entire series with an MIC value of $12.5 \mu \mathrm{g} / \mathrm{mL}$ (Figure 5). Increasing the aliphatic chain led to loss of activity and oxidation of the hydroxyl group at the 4th position was deleterious for activity. 2,10-dihydro4aH-chromeno [3,2-c] pyridin-3-yl analogs were synthesized and evaluated for their activity against $M t b \mathrm{H}_{37} \mathrm{Rv}$ and multi-drug resistant M. tuberculosis (MDR-TB) [49]. Three compounds 10 (ac) inhibited $M t b$ with MIC values of less than $1 \mu \mathrm{M}$ and compound $10 \mathrm{a}(\mathrm{MIC}=0.22 \mu \mathrm{M})$ was more potent than isoniazid $(\mathrm{MIC}=0.36 \mu \mathrm{M})$ (Figure 6). All the 2,10-dihydro-4aH-chromeno[3,2-c]pyridin3-yl analogs inhibited the MDR-TB clinical isolate with MIC values ranging from 0.07 to $7.09 \mu \mathrm{M}$ and were found to be more active than standard drugs isoniazid $(\mathrm{MIC}=45.57 \mu \mathrm{M})$, ofloxacin $(\mathrm{MIC}=34.39 \mu \mathrm{M})$ and ethambutol $(\mathrm{MIC}=122.36 \mu \mathrm{M})$.

In this series, antimycobacterial activity was enhanced by the introduction of an electron donating methyl group on the pyridyl moiety, whereas introduction of weakly deactivating and electron withdrawing dibromo groups decreased the activity. Replacement of phenyl ring with naphthyl moiety enhanced the activity 4-8 times, and further introduction of a methyl group on the naphthyl moiety enhanced the activity 2-fold. Replacement of phenyl ring with phenoxymethyl group was detrimental to activity. Compound
$10 \mathrm{a}$ was found to be non-toxic up to $62.5 \mu \mathrm{g} / \mathrm{mL}$ with selectivity index (IC ${ }_{50} / \mathrm{MIC}$ ) of more than 629 for $M t b$ and 1977 for MDRTB. Subsequently, compound 10 a was tested for in vivo efficacy against $M t b$ at a dose of $25 \mathrm{mg} / \mathrm{kg}$ in $\mathrm{CD}^{-1}$ mice. The compound decreased bacterial load in lung and spleen tissues with 1.11 and 2.94- $\log 10$ protections respectively but was found to be less active than isoniazid at the same dose level.

Nalla et al. [50] described the synthesis of chromone embedded [1,2,3]-triazole derivatives and screened for their in vitro antitubercular activity against $M t b \mathrm{H}_{37} \mathrm{Rv}$ using the MABA method. Compound 11 was the most potent compound in vitro with an MIC value of $1.56 \mu \mathrm{g} / \mathrm{mL}, 4.8$ times more active than the standard drug ethambutol (MIC, $7.64 \mu \mathrm{g} / \mathrm{mL}$ ) (Figure 6). Modification on the triazole core by changing the substituents from aromatic to aliphatic groups (cyclic or acyclic) enhances the activity against $M t b$. Furthermore, substitution on the phenyl ring with alkyl groups such as 4-methyl, 4-ethyl, 4-propyl and 4-pentyl do not favor better activity, except for 4-t-butyl group. The same group also performed molecular docking studies which identified enoyl acyl carrier protein reductase as the potential target. This enzyme plays a role in mycolic acid biosynthesis. Khan et al. [51] demonstrated the synthesis of (2-Amino-3-cyano-4H-chromen-4yl)-phosphonates and screened for their antitubercular activity against $M t b \mathrm{H}_{37} \mathrm{Rv}$ using disc diffusion susceptibility method [52].<smiles>[R]C(=O)NCC1=CC2Oc3ccccc3C(=O)C2=CN1c1ncccc1C</smiles>

$10(\mathrm{a}-\mathrm{c})$

a) $\mathrm{R}=4$-ethylphenyl; $\mathrm{MIC}\left(\mathrm{Mtb} \mathrm{H}_{37} \mathrm{Rv}\right)=0.22 \mu \mathrm{M}$ $\operatorname{MIC}(M D R-T B)=0.07 \mu \mathrm{M}$

b) $\mathrm{R}=2$-naphthyl; $\mathrm{MIC}\left(\mathrm{Mtb} \mathrm{H}_{37} \mathrm{Rv}\right)=0.84 \mu \mathrm{M}$ $\operatorname{MIC}(M D R-T B)=0.42 \mu \mathrm{M}$

c) $\mathrm{R}=7$-methylnaphth-2-yl; $\mathrm{MIC}\left(\mathrm{Mtb} \mathrm{H}_{37} \mathrm{Rv}\right)=0.41 \mu \mathrm{M}$ MIC $(M D R-T B)=0.13 \mu \mathrm{M}$<smiles>CC(C)Cc1cn(Cc2coc3ccccc3c2=O)nn1</smiles>

11

$\operatorname{MIC}\left(M t b \mathrm{H}_{37} \mathrm{Rv}\right)=1.56 \mu \mathrm{g} / \mathrm{mL}$

Figure 6: 2,10-dihydro-4aH-chromeno[3,2-c] pyridin-3-yl and 1,2,3-triazole chromone compounds.

Compound 12a exhibited strong antitubercular activity with an MIC value of $10 \mu \mathrm{g} / \mathrm{mL}$, equaling that of standard antitubercular drug isoniazid (Figure 7). It is evident from the SAR that electron withdrawinggroups on the phenyl ring; particularly, the nitro group enhances antitubercular activity of the chromenylphosphonates, while electron donating groups result in loss of potency. Molecular docking calculations predicted strong affinity of $12 \mathrm{a}$ towards salmon milt (sm-DNA) with a binding affinity $(\Delta \mathrm{G})-7.4 \mathrm{Kcal} /$ mol [51]. The compound exhibited selective affinity towards adeninethiamine (A-T) base pairs. Non-covalent interactions, $\mathrm{H}$-bonding and van der Waals forces were predicted as the driving forces of interaction.

Laxmi et al. [53] reported the synthesis of 6-methyl-4,8dioxo-4,8-dihydropyrano[3,2-g] chromenes and evaluated their antitubercular properties against $M t b \mathrm{H}_{37} \mathrm{RV}$ in BACTEC 12B medium. Analog 13 was identified as the most potent inhibitor 
against $M t b$, with an MIC value $\left(\mathrm{IC}_{90}\right.$ ) of $5.90 \mu \mathrm{g} / \mathrm{mL}$ in the MABA assay. Its antitubercular activity was superior to that of the antitubercular drug, pyrazinamide (PZA; $\mathrm{IC}_{90}>20 \mu \mathrm{g} / \mathrm{mL}$ ) (Figure 7). However, the compound was toxic to Vero cell lines with selectivity index (SI) of 2.41. Interestingly, the inactivity of the structurally related analogs indicates that the presence of the C8methyl group in 13 may be critical for antitubercular activity. Thus, compound 13 could be a lead for subsequent optimization in the search for novel antitubercular agents. Tantry et al. [54] identified a novel class of spirochromenes from a whole cell-based screen of spiropiperidine series comprising of three closely related classes of compounds namely, spiroindenes, spiroindolones and spirochromenes to identify leads against $M t b$.

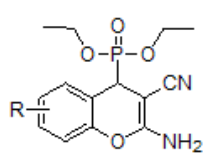

12 (a-d)

a) $\mathrm{R}=7$-nitro; $\mathrm{MIC}\left(\mathrm{Mtb}_{\mathrm{t}} \mathrm{H}_{37} \mathrm{Rv}\right)=10 \mu \mathrm{g} / \mathrm{mL}$

b) $\mathrm{R}=6-\mathrm{Cl}$; $\mathrm{MIC}\left(\mathrm{Mtb}_{3} 7 \mathrm{Rv}\right)=20 \mu \mathrm{g} / \mathrm{mL}$

c) $\mathrm{R}=6-\mathrm{Br} ; \mathrm{MIC}\left(\mathrm{Mtb} \mathrm{H}_{37} \mathrm{Rv}\right)=20 \mu \mathrm{g} / \mathrm{mL}$

d) $\mathrm{R}=\mathrm{H} ; \mathrm{MIC}\left(\mathrm{Mtb}_{37} \mathrm{Rv}\right)=60 \mu \mathrm{g} / \mathrm{mL}$

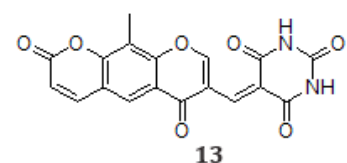

$\mathrm{IC}_{50}\left(\mathrm{Mtb} \mathrm{H}_{37} \mathrm{Rv}\right)=4.71 \mu \mathrm{g} / \mathrm{mL}$ $\mathrm{IC}_{90}\left(\mathrm{Mtb} \mathrm{H}_{37} \mathrm{Rv}\right)=5.90 \mu \mathrm{g} / \mathrm{mL}$

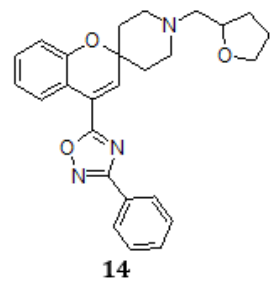

$\operatorname{MIC}\left(M t b \mathrm{H}_{3} 7 \mathrm{Rv}\right)=0.8 \mu \mathrm{M}$

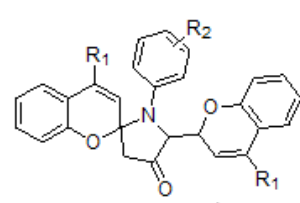

15

a) $\mathrm{R}_{1}=\mathrm{OH}, \mathrm{R}_{2}=p-\mathrm{NO}_{2} \mathrm{C}_{6} \mathrm{H}_{5} ; \mathrm{MIC}(\mathrm{MTCC}, 300)=10 \mu \mathrm{g} / \mathrm{mL}$

b) $\mathrm{R}_{1}=\mathrm{H}, \mathrm{R}_{2}=p-\mathrm{NO}_{2} \mathrm{C}_{6} \mathrm{H}_{5} ; \mathrm{MIC}(\mathrm{MTCC}, 300)=20 \mu \mathrm{g} / \mathrm{mL}$

c) $\mathrm{R}_{1}=\mathrm{OH}, \mathrm{R}_{2}=o-\mathrm{NO}_{2} \mathrm{C}_{6} \mathrm{H}_{5} ; \mathrm{MIC}(\mathrm{MTCC}, 300)=30 \mu \mathrm{g} / \mathrm{mL}$

Figure 7: Structures of benzopyran derivatives 12-15.

This was followed by re-synthesis of the active compounds and profiling for antitubercular activity. Among these compounds spirochromene 14 was potent with an MIC value of $0.8 \mu \mathrm{M}$ (Figure 7). Since spiroindenes were the largest subseries with good potency spread widely in the spiropiperidine series, it was further investigated ahead of the spirochromenes. However, whole genome sequencing efforts of the spiroindene resistant mutants resulted in the identification of $1292 \mathrm{~L}$ mutation in Mycobacterial membrane protein Large (MmpL3) required for the assembly of mycolic acid into the cell wall core of $M t b$.

Khan et al. [55] reported a facile multicomponent one pot synthesis of spiro [chromene-2, 2-pyrollidin]-4'-one derivatives. The antitubercular activity of synthesized compounds was investigated against Mtb (MTCC, 300) using the agar dilution method. The electron withdrawing groups in the phenyl ring, particularly the nitro group reinforced the antitubercular activity of the chromeno derivatives. The higher activity could be due to the nitro group contributing hydrogen bonding atoms resulting in favorable substrate-inhibitor interactions. The hydroxyl groups could also be improving the potency in a similar fashion. Among the nitro derivatives $15(\mathrm{a}-\mathrm{c})$ the para-nitro substituted derivatives are more active compared to ortho substituted ones. Enzyme docking studies of 15 also indicated a high affinity for the enoyl acyl carrier protein reductase. Warekar et al. [56] illustrated the synthesis of 1,2-bis(4-nitrophenyl)-1H-benzo[f]chromen-3-amine derivatives and were evaluated for their in vitro antitubercular activity against $M t b \mathrm{H}_{37} \mathrm{RV}$ strain.

Compound 16 was the most potent with MIC $=1.6 \mu \mathrm{g} / \mathrm{mL}$, better than standard drugs pyrazinamide and streptomycin (Figure 8). Angelova et al. [57] reported the synthesis of $2 \mathrm{H}$-chromene derivatives with various substituted hydrazide-hydrazone pharmacophore attached to the $3^{\text {rd }}$ position of the chromene ring. The synthesized compounds were evaluated in vitro against $M t b$ $\mathrm{H}_{37} \mathrm{Rv}$, using the Canetti method [58]. Compound 17 was amongst the most potent compounds in the series with an MIC value of $0.17 \mu \mathrm{M}$, better than isoniazid ( $\mathrm{MIC}=1.45 \mu \mathrm{M})$. Furthermore, the potent compounds were investigated for cytotoxicity against human embryonal kidney cell line HEK-293T and compound 17 displayed the second-best selectivity index of 448 .

Tripathi et al. [59] reported synthesis of a series of hybrid molecules bearing a benzopyran skeleton and evaluated them against both avirulent $\left(\mathrm{H}_{37} \mathrm{Ra}\right)$ and virulent $\left(\mathrm{H}_{37} \mathrm{Rv}\right)$ strains of $M t b$ using the agar microdilution method. Most of the compounds were active against the virulent strain, $M t b \mathrm{H}_{37} \mathrm{Rv}$ with MIC values ranging from $1.56-12.5 \mu \mathrm{g} / \mathrm{mL}$, while the same compounds were 
inactive against the avirulent strain, indicating the selectivity of these compounds towards the virulent strain. From the 4-(1-(2,2-dimethylchroman-6-yl)-3-phenylprop-2-ynyl) cyclic amines series, compounds 18 (a-c) had the most improved antitubercular activity with MIC values of $1.56,3.12$ and $6.12 \mu \mathrm{g} /$
$\mathrm{mL}$ respectively (Figure 8). From the SAR, the morpholine moiety was bad for activity compared to piperidine. This enhanced activity with the piperidine could be due to increased lipophilicity since it is devoid of the polar oxygen. Also, the aromatic ring resulted in loss of activity compared to aliphatic chains.

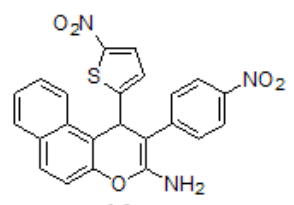

16

$\operatorname{MIC}\left(\mathrm{Mtb}_{3} \mathrm{H}_{7} \mathrm{Rv}\right)=1.6 \mu \mathrm{g} / \mathrm{mL}$

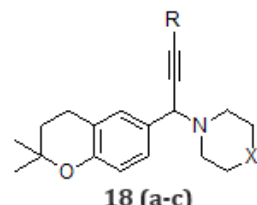

a) $\mathrm{R}=\left(\mathrm{CH}_{2}\right)_{5} \mathrm{CH}_{3}, \mathrm{X}=\mathrm{CH}_{2} ; \mathrm{MIC}\left(M t b \mathrm{H}_{3} \mathrm{Rv}\right)=1.56 \mu \mathrm{g} / \mathrm{mL}$

b) $\mathrm{R}=\left(\mathrm{CH}_{2}\right)_{4} \mathrm{CH}_{3}, \mathrm{X}=0$; $\mathrm{MIC}\left(M t b \mathrm{H}_{37} \mathrm{Rv}\right)=3.12 \mu \mathrm{g} / \mathrm{mL}$

c) $\mathrm{R}=\mathrm{C}_{6} \mathrm{H}_{5}, \mathrm{X}=\mathrm{CH}_{2}$; MIC $\left(M t b \mathrm{H}_{3} 7 \mathrm{Rv}\right)=6.25 \mu \mathrm{g} / \mathrm{mL}$<smiles></smiles>

$\operatorname{MIC}\left(M t b \mathrm{H}_{37} \mathrm{Rv}\right)=0.17 \mu \mathrm{M}$

Figure 8: Structures of benzo[f]chromen-3-amine, $2 \mathrm{H}$-chromene and substituted chroman compounds.

Prado et al. [60] reported the synthesis of benzofuro[3,2-f] [1] benzopyrans and screened them for antimycobacterial activity against various strains of $M t b$. Both 3,3-dimethyl-3H benzofuro[3,2-f][1]benzopyran and 1,2-dihydro-3,3-dimethyl-3H benzofuro[3,2-f][1]benzopyran displayed significant activities when tested against $M t b \mathrm{H}_{37} \mathrm{Rv}$ with $\mathrm{MIC}_{99}$ values of $5 \mu \mathrm{g} / \mathrm{mL}$. Both compounds 19 and its reduced analog 20 were found to be more potent than isoniazid (INH) when tested for inhibitory activity on M. smegmatis $\mathrm{mc}^{2} 155$ strain. In addition, similar $\mathrm{MIC}_{99}$ values were obtained for compounds 19 and 20 on other mycobacterial strains such as $M t b \mathrm{H}_{37} \mathrm{Ra}$ as well as BCG (Bacillus CalmetteGuérin) (Figure 9).

Functionalization with the aim of improving solubility in biocompatible solvents, such as dihydroxylation of the pyranodibenzofuran ring and subsequent conversion into esters resulted in complete loss of activity. The same research group carried out structure activity relationship studies on compounds 19 and 20 in a bid to improve the physicochemical properties of the scaffold [61]. The compounds were screened for their antimycobacterial activity on the fast-growing saprophyte $\mathrm{M}$. smegmatis $\mathrm{mc}^{2} 155$ and on the virulent strain $M t b \mathrm{H}_{37} \mathrm{Rv}$, using the microdilution resazurin assay (MRA) [62]. However, their efforts were rather unsuccessful as the linear tetracyclic analogs were less active and cytotoxic compared to their isomers 19 and 20. Only compound 21 among the tetracyclic analogs showed moderate activity $\left(\mathrm{MIC}_{99}=35 \mu \mathrm{g} / \mathrm{mL}\right.$ ) (Figure 9). The same research team further expanded their SAR studies towards the synthesis of furo[3,2-f] chromenes derivatives.

The synthesized compounds were also screened for antimycobacterial activity on the same strains following the MRA method. From the screened furo[3,2-f] chromenes derivatives, two compounds (22 (a-b)) showed improved activity from 19 and 20 (Figure 9). From the SAR, replacement of the pyridyl ring with a phenyl or methyl group resulted in loss of activity. The introduction of aliphatic chains on C3 of the furan ring led to disappointing antitubercular activity [63]. Termentzi et al. [64] further reported the synthesis of 8-, 9-, 10-, and 11-halo, hydroxy, and methoxy substituted derivatives of the antimycobacterial 3,3-dimethyl3 H-benzofuro[3,2-f][1]benzopyran (19). The antimycobacterial activities of the substituted benzofurobenzopyrans were screened on Mycobacterium bovis BCG and $M t b \mathrm{H}_{37}$ Rv using the MRA method.

All the compounds substituted on the phenyl ring were more potent than the reference compound 19 against $M t b \mathrm{H}_{37} \mathrm{RV}$ strain, indicating that substitution on the benzofurobenzopyran core with hydroxy, methoxy and halogen groups enhanced the antimycobacterial activity. The good activity of hydroxylated compounds 23 (a-b), was unfortunately, accompanied by strong in vitro cytotoxicity against vero cells (Figure 9). The order of activity with this substituted compound is Hydroxy > Methoxy > Halides. These biological results suggest that the substitution on the phenyl ring by an electron-withdrawing group leads to less active compounds. On the contrary, substitution with electron- 
donating hydroxy or methoxy groups significantly enhances the antimycobacterial activity. Enzyme inhibition studies of these compounds suggest a mode of action that involves the inhibition of mycobacterial cell wall lipid biosynthesis.

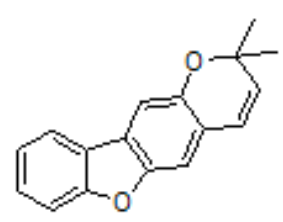

21

$\mathrm{MIC}_{99}\left(\mathrm{Mtb} \mathrm{H}_{37} \mathrm{Rv}\right)=35 \mu \mathrm{g} / \mathrm{mL}$ MIC99 (M. smegmatis) $=20 \mu \mathrm{g} / \mathrm{mL}$

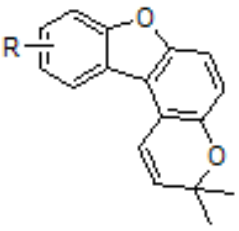

23 (a-b)

$\mathrm{R}=8-\mathrm{OH} ; \mathrm{MIC}_{95}\left(\mathrm{Mtb} \mathrm{H}_{37} \mathrm{Rv}\right)=23.5 \mu \mathrm{M}$

$\operatorname{MIC}_{95}(\mathrm{M}$. bovis $)=94 \mu \mathrm{M}$

$\mathrm{R}=9-\mathrm{OH} ; \mathrm{MIC}_{95}\left(\mathrm{Mtb} \mathrm{H}_{37} \mathrm{Rv}\right)=23.5 \mu \mathrm{M}$

$\mathrm{MIC}_{95}(\mathrm{M}$. bovis $)=94 \mu \mathrm{M}$

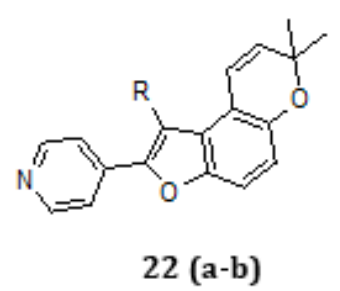

$\mathrm{R}=\mathrm{H} ; \mathrm{MIC}_{95}\left(\mathrm{Mtb} \mathrm{H}_{37} \mathrm{Rv}\right)=2.5 \mu \mathrm{g} / \mathrm{mL}$ $\operatorname{MIC}_{95}$ (M. smegmatis) $=3 \mu \mathrm{g} / \mathrm{mL}$

$\mathrm{R}=\mathrm{Me} ; \mathrm{MIC}_{95}\left(\mathrm{Mtb} \mathrm{H}_{37} \mathrm{Rv}\right)=3 \mu \mathrm{g} / \mathrm{mL}$ MIC95 (M. smegmatis) $=6.2 \mu \mathrm{g} / \mathrm{mL}$

Figure 9: Structures of furobenzopyran compounds.

Ganihigama et al. [65] reported the synthesis of densely functionalized chromenes with various substitutions such as dimedone, indole and benzotriazole. The chromenes were screened for antimycobacterial activity against the non-virulent $\mathrm{H}_{37} \mathrm{Ra}$ strain of $M t b$ following the MABA method. Compound 24 was the most active chromene with an MIC value of $25.0 \mu \mathrm{g} /$ $\mathrm{mL}$ (Figure 10). Substituting the naphthalene ring for a phenyl resulted in loss of activity. Furthermore, substitution on the phenyl ring with hydroxyl or methoxy groups resulted in 3-fold loss in activity. Kamdar et al. [66] reported the design, synthesis and antitubercular activity of chromeno[2,3-d] pyrimidine-2-thiones. The compounds were evaluated for their in vitro antitubercular activity against $M t b \mathrm{H}_{37} \mathrm{Rv}$. Quinoline substituted compound 25 had the highest activity, exhibiting inhibition at $62.5 \mu \mathrm{g} / \mathrm{mL}$ which was comparable to that of standard drug rifampicin $(40 \mu \mathrm{g} / \mathrm{mL})$. Replacement of the quinolone moiety with a naphthalene resulted in loss of activity. Also, phenyl and phenol replacements did not improve the antitubercular activity. The same research group also described the synthesis of $4 \mathrm{H}$-chromeno[2,3-d] pyrimidines and evaluated them for their in vitro antitubercular activity against $M t b \mathrm{H}_{37} \mathrm{Rv}$. From the biological data, pyrimidin-4-one 26 showed the best activity (MIC $=62.5 \mu \mathrm{g} / \mathrm{mL}$ ) against mycobacteria (Figure 10) [67].

Haveliwa et al. [68] further reported the synthesis of chromone fused cytosine analogs derivatives and were investigated against $M t b \mathrm{H}_{37} \mathrm{Rv}$ using the Lowenstein-Jensen (L-J) method. Compound 27 was the most effective against $M t b \mathrm{H}_{37} \mathrm{Rv}$ strain with $99 \%$ inhibition at $40 \mu \mathrm{g} / \mathrm{mL}$ concentration. The introduction of electron withdrawing groups such as the 7-chloro substitution enhanced activity while electron donation groups were deleterious for activity. Haveliwa et al. [69] synthesized a series of chromone-fused thiopyrimidines and investigated their antitubercular activity against $M t b \mathrm{H}_{37} \mathrm{Rv}$ at a concentration of $62.5 \mu \mathrm{g} / \mathrm{mL}$. Compound 28 with the dibromo group on the phenyl ring of the chromone depicted the highest inhibition (Figure 11). Similarly, electron withdrawing halogen substituents improved the inhibitory activity compared to methyl substituents. The same research team further reported the synthesis of functionalized H- [1] benzopyrano [2,3b] pyridine derivatives by the Friedländer reaction of 2-amino-4- 
oxo-4H-chromene-3-carbonitriles with ethyl cyanoacetate. The compounds were investigated for their antitubercular activity against $M t b \mathrm{H}_{37} \mathrm{Rv}$ at a concentration of $62.5 \mu \mathrm{g} / \mathrm{mL}$, using the L-J method. In this experiment, compound 29 was the most effective against $M t b \mathrm{H}_{37} \mathrm{Rv}$ strain with $99 \%$ inhibition [70].

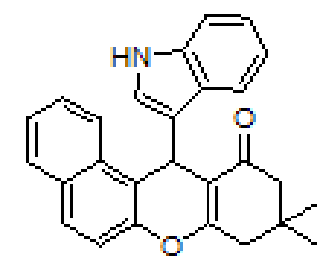

24<smiles>COc1ccc(C2c3ccc4cccnc4c3Oc3[nH]c(=S)nc(N)c32)cc1</smiles>

25<smiles>O=c1[nH]cnc2c1C(c1ccccc1)c1ccc(O)cc1O2</smiles>

26

$\mathrm{MIC}_{99}\left(\mathrm{Mtb} \mathrm{H}_{37} \mathrm{Ra}\right)=25 \mu \mathrm{g} / \mathrm{mL}$

$\operatorname{MIC}\left(M t b \mathrm{H}_{37} \mathrm{Rv}\right)=62.5 \mu \mathrm{g} / \mathrm{mL}$

$\operatorname{MIC}\left(M t b \mathrm{H}_{37} \mathrm{Rv}\right)=62.5 \mu \mathrm{g} / \mathrm{mL}$<smiles>Nc1nc(=O)[nH]c2oc3ccc(Cl)cc3c(=O)c12</smiles>

27<smiles>NC(N)=Nc1nc(=S)[nH]c2oc3c(Br)cc(Br)cc3c(=O)c12</smiles>

28

$\% \operatorname{inh}(62.5 \mu \mathrm{g} / \mathrm{mL})=99$<smiles>N#Cc1c(N)c2c(=O)c3cc([N+](=O)[O-])ccc3oc2[nH]c1=O</smiles>

29

$\% \operatorname{inh}(62.5 \mu \mathrm{g} / \mathrm{mL})=99$

Figure 11: Structures of fused chromone compounds.

Balasubramania et al. [71] reported the synthesis of triazolechromene hybrids and screened them for their in vitro activity against $M t b \mathrm{H}_{37} \mathrm{Rv}$ following the MABA method. Naphthoquinonetriazole-chromene hybrid 30 with $\mathrm{IC}_{90}=9.86 \mu \mathrm{M}$ was more potent than standard anti-TB drugs cycloserine and pyrimethamine (Figure 12). The results demonstrate that triazole-chromene hybrids with a fluoro substituted aniline are more active than the other compounds and 6-chloro substitution on the chromene ring improves activity while 6-bromo substitution was unfavorable for antitubercular activity. Khare et al. [72] synthesized 1,2,3-triazolechromene conjugates and evaluated them for their in vitro antitubercular activity against $M t b \mathrm{H}_{37} \mathrm{Rv}$ strain. Compounds 31 (a-b) were the most effective in terms of inhibiting mycobacterial growth with $\mathrm{MIC}=12.5 \mu \mathrm{g} / \mathrm{mL}$.

The antitubercular activity depends upon substituents present on phenyl ring, as well as the position of the substituents on the phenyl ring. Electron withdrawing substituents such as $\mathrm{R}=4-\mathrm{Cl}$ and $\mathrm{R}=\mathrm{NO}_{2}$ demonstrated improved antitubercular activity, compared to electron donating groups such as $\mathrm{R}=4-\mathrm{OMe}$ and $\mathrm{R}=4-\mathrm{Me}$. Furthermore, the position of the substituent was found to be important for activity as observed with the nitro substituents, favoring the para position ahead of the ortho and meta substitutions. Docking studies showed significant binding affinity in the active site of Mycobacterium tuberculosis DprE1 enzyme. Triazole-fused spirochromenes were synthesized and evaluated against $M t b \mathrm{H}_{37} \mathrm{Rv}$ strain following the MABA assay [73].

Compounds 32 (a-c) possess higher inhibitory activity than standard drug ethambutol $(7.64 \mu \mathrm{M})$ (Figure 12). No evident SAR trend could be deduced from the different substituents in the phenyl ring. However, substituting the phenyl ring for a benzyl moiety by the triazole side of the prototype led to 8 to 15 -fold loss in activity. Muthukhrishnan et al. [74] synthesized a series of 1,2,3-triazole fused spirochromone conjugates and screened them for their in vitro antimycobacterial activity against M. tuberculosis $\mathrm{H}_{37} \mathrm{Rv}$. The compounds displayed significant in vitro activity against $M t b$, with compound 33 the most potent (MIC=0.78 $\mu \mathrm{g}$ / $\mathrm{mL}$ ) and found to be better than first line antimycobacterial drug ethambutol $(1.56 \mu \mathrm{g} / \mathrm{mL})$. The SAR reveals that compounds with a cyclohexyl group at the $2^{\text {nd }}$ position of the chromone ring show better activity than piperidinyl moiety. Furthermore, aromatic 
substitution at the $4^{\text {th }}$ position of the triazole was favorable than alkyl substitution. Moreover, alkyl substituents on the aromatic ring improve activity.

Alvey etal. [75] reported the synthesis of furo[3,2-f] chromanes and investigated their effect on the growth of Mycobacterium bovis BCG as well as on the virulent strain $M t b \mathrm{H}_{37} \mathrm{Rv}$, using the MRA method. Among the synthesized furo[3,2-f] chromanes, chromane 34, was the most potent with MIC95 $=0.6 \mu \mathrm{g} / \mathrm{mL}$ (Figure 12). However, many analogs which inhibited the growth of $M$. tuberculosis in the $0.6-5 \mu \mathrm{g} / \mathrm{mL}$ range (including chromane 34 ) turned out to be cytotoxic on vero cells at the same concentration range. Li et al. [76] described the synthesis of 2-azacyclo-5trifluoromethyl-8-nitrobenzopyran-4-one derivatives (35-37) and assessed their minimum inhibitory concentration (MIC) to $M t b \mathrm{H}_{37} \mathrm{Rv}$ strain using the MABA method. The compounds exhibited good antitubercular activity, which is comparable with standard drugs, but were inferior to their benzothiopyran-4-one counterparts (Figure 13). However, both the benzothiopyranones and benzopyranones together with benzoxazinones were designed through scaffold morphing from benzothiazinones to target DprE1.

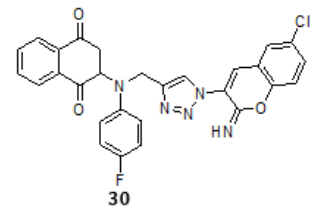

$\mathrm{IC}_{50}\left(\mathrm{Mtb} \mathrm{H} \mathrm{H}_{37} \mathrm{Rv}\right)=3.18 \mu \mathrm{M}$

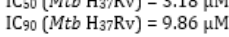
$\operatorname{MIC}\left(M t b \mathrm{H}_{3} \mathrm{Rv}\right)=25.0 \mu \mathrm{M}$

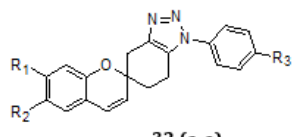

32 (a-e)

a) $\mathrm{R}_{1}=\mathrm{H} ; \mathrm{R}_{2}=\mathrm{Cl}, \mathrm{R}_{3}=\mathrm{OMe} ; \mathrm{MIC}\left(\right.$ Mtb $\left.\mathrm{H}_{3} 7 \mathrm{Rv}\right)=4.11 \mu \mathrm{M}$ b) $\mathrm{R}_{1}=\mathrm{H} ; \mathrm{R}_{2}=\mathrm{Me}, \mathrm{R}_{3}=\mathrm{H} ; \mathrm{MIC}\left(\right.$ Mtb $\left.\mathrm{H}_{3} 7 \mathrm{Rv}\right)=4.74 \mu \mathrm{M}$ c) $\mathrm{R}_{1}=\mathrm{H} ; \mathrm{R}_{2}=\mathrm{Me}, \mathrm{R}_{3}=\mathrm{OMe}$; MIC $\left(M t b \mathrm{H}_{3} 7 \mathrm{Rv}\right)=4.34 \mu \mathrm{M}$ d) $\mathrm{R}_{1}=\mathrm{Me} ; \mathrm{R}_{2}=\mathrm{Cl}, \mathrm{R}_{3}=\mathrm{Cl} ; \mathrm{MIC}\left(M t b \mathrm{H}_{3} 7 \mathrm{Rv}\right)=7.87 \mu \mathrm{M}$ e) $\mathrm{R}_{1}=\mathrm{Me} ; \mathrm{R}_{2}=\mathrm{Cl}, \mathrm{R}_{3}=\mathrm{H} ; \mathrm{MIC}\left(M t b \mathrm{H}_{3} 7 \mathrm{Rv}\right)=8.60 \mu \mathrm{M}$<smiles>CCCCCc1ccc(-c2cn(CC(O)COc3ccc4c(c3)OC3(CCCCC3)CC4=O)nn2)cc1</smiles>

33

$\operatorname{MIC}_{95}\left(M_{t b} \mathrm{H}_{37} \mathrm{Rv}\right)=0.78 \mu \mathrm{g} / \mathrm{mL}$

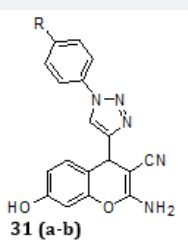

a) $\mathrm{R}=\mathrm{NO}_{2} ; \mathrm{MIC}\left(\mathrm{Mtb} \mathrm{H}_{3} 7 \mathrm{Rv}\right)=12.5 \mu \mathrm{g} / \mathrm{mL}$ b) $\mathrm{R}=\mathrm{Cl} ; \mathrm{MIC}\left(\mathrm{Mtb} \mathrm{H}_{3} 7 \mathrm{Rv}\right)=12.5 \mu \mathrm{g} / \mathrm{mL}$

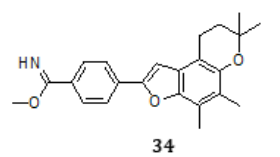

$\operatorname{MIC}_{95}(M t b \mathrm{H} 37 \mathrm{Rv})=0.6 \mu \mathrm{g} / \mathrm{mL}$

Figure 12: Structures of triazole benzopyran hybrids and furo[3,2-f] chromane compounds.<smiles>CC1COC2(CCN(c3cc(=O)c4cc(C(F)(F)F)cc([N+](=O)[O-])c4o3)CC2)O1</smiles>

$\mathrm{MIC}_{90}\left(\mathrm{Mtb}_{37} \mathrm{Rv}\right)<0.016 \mu \mathrm{g} / \mathrm{mL}$<smiles>O=c1cc(N2CCN(CC3CCCCC3)CC2)oc2c([N+](=O)[O-])cc(C(F)(F)F)cc12</smiles>

36<smiles>O=C1CN(c2cc(=O)c3cc(C(F)(F)F)cc([13O])c3o2)CCN1CC1CCCCC1</smiles>

$\mathrm{MIC}_{90}\left(\mathrm{Mtb} \mathrm{H}_{37} \mathrm{Rv}\right)=0.091 \mu \mathrm{g} / \mathrm{mL}$<smiles>CCOC(=O)NC(=O)c1ccsc1NC(=O)C1=Cc2cccc(OC)c2OC1</smiles>

38<smiles>CCOC(=O)NC(=O)c1ccsc1NC(=O)C1=Cc2ccccc2OC1</smiles>

39<smiles>CCOC(=O)NC(=O)c1ccsc1NC(=O)C1COc2ccc(OC)cc2C1</smiles>

40

MIC $\left(\right.$ Mtb $\left.\mathrm{H}_{37} \mathrm{Rv}\right)<1 \mu \mathrm{g} / \mathrm{mL}$

MIC $\left(M t b \mathrm{H}_{37} \mathrm{Rv}\right)<1 \mu \mathrm{g} / \mathrm{mL}$

Figure 13: Structures of compounds (35-40). 
Chatterjee et al. [77] reported the synthesis of substituted thiophene heterocycles and investigated them as potential drugs for treatment of drug resistant and persistent tuberculosis. These compounds were evaluated against $M t b \mathrm{H}_{37} \mathrm{Rv}$ strain following the MABA method. Compounds 38-40 showed great potency with MIC values less than $3.0 \mu \mathrm{g} / \mathrm{mL}$ (Figure 13). Interestingly, these compounds were not cytotoxic with selectivity index greater than 50 when evaluated on Vero cells. From the SAR, reduction of the pyran ring resulted in partial loss of activity. Whole genome sequencing of the genomic DNA of the resistant mutants revealed that they all have a single point mutation resulting in the amino acid replacement Tyr321Cys in MSMEG 6382 and Tyr314Cys in rv3790. rv3790, encodes DprEl, a component of the essential decaprenylphosphoryl-B-D-ribofuranose 2'-epimerase (DprEl / DprE2) required for cell wall arabinan biosynthesis.

Ananthan et al. [78] reported anti-TB activities of a library of compounds obtained from the tuberculosis antimicrobial acquisition and coordinating facility (TAACF). Amongst the active compounds, identified via whole cell high throughput screening, was a series of multi-substituted benzopyran-4-ones. In total, 68 compounds were screened against $M t b \mathrm{H}_{37} \mathrm{Rv}$ strain and $51 \%$ of these showed above $90 \%$ bacterial inhibition in the primary single dose assay. Compounds 41 (a-e) displayed potent antitubercular activity with MICs ranging from $0.43-1.8 \mu \mathrm{g} / \mathrm{mL}$ (Figure 14). In general, compounds with substituents on $\mathrm{C} 3$ and $\mathrm{C} 7$ were the most potent and any substituent could be tolerated. Aromatic substituents directly attached to C3 through carbon were more favourable than those attached through oxygen.

A variety of esters composed of methyl, ethyl, cyclohexyl, and benzyl groups were found to be good for activity. Change in potency was not observed when $\mathrm{C} 2$ was substituted with a methyl group. Also, replacing the hydrogen on C8 with a methyl did not improve the potency of the compounds. Swaroop et al. [79] reported the synthesis of diaportheone B, one of the two benzopyranones isolated from endophytic fungus Diaporthe sp. P133 [80]. Several close analogs of diaportheone $B$ were synthesized and their antiTB potential was determined against $M t b \mathrm{H}_{37} \mathrm{Rv}$ using the MABA method. Diaportheone B (42), its enantiomer (43) and the racemic mixture showed very similar activity $(10-12.5 \mu \mathrm{g} / \mathrm{mL})$. With an MIC value of $6.25 \mu \mathrm{g} / \mathrm{mL}$, compound 44 is the only analog that exhibit superior activity compared to the natural product, diaportheone B (Figure 14).<smiles>[R9]C(=O)COc1ccc2c(=O)c([R6])c(Br)oc2c1N</smiles>

a) $\mathrm{R}_{1}=\mathrm{H}, \mathrm{R}_{2}=2$ methylphenyl, $\mathrm{R}_{3}=\mathrm{H}, \mathrm{R}_{4}=\mathrm{Et} ; \mathrm{MIC}_{90}\left(M t b \mathrm{H}_{37} \mathrm{Rv}\right)=0.43 \mu \mathrm{g} / \mathrm{mL}$

b) $\mathrm{R}_{1}=\mathrm{H}_{1} \mathrm{R}_{2}=2$ ethylphenyl, $\mathrm{R}_{3}=\mathrm{H}, \mathrm{R}_{4}=\mathrm{C}_{6} \mathrm{H}_{11} ; \mathrm{MIC}_{90}\left(M t b \mathrm{H}_{3} 7 \mathrm{Rv}\right)=0.47 \mu \mathrm{g} / \mathrm{mL}$

c) $\mathrm{R}_{1}=\mathrm{CH}_{3}, \mathrm{R}_{2}=2$ chlorophenyl, $\mathrm{R}_{3}=\mathrm{H}, \mathrm{R}_{4}=\mathrm{CH}_{3} ; \mathrm{MIC} 90\left(M t b \mathrm{H}_{3} \mathrm{Rv}\right)=0.82 \mu \mathrm{g} / \mathrm{mL}$

d) $\mathrm{R}_{1}=\mathrm{H}, \mathrm{R}_{2}=2$ chlorophenyl, $\mathrm{R}_{3}=\mathrm{H}, \mathrm{R}_{4}=\mathrm{CH}_{3} ; \mathrm{MIC}_{90}\left(M t b \mathrm{H}_{37} \mathrm{Rv}\right)=0.86 \mu \mathrm{g} / \mathrm{mL}$

e) $\mathrm{R}_{1}=\mathrm{CH}_{3}, \mathrm{R}_{2}=2$ chlorophenyl, $\mathrm{R}_{3}=\mathrm{CH}_{3}, \mathrm{R}_{4}=\mathrm{Et} ; \mathrm{MIC}_{90}\left(M t b \mathrm{H}_{3} \mathrm{Rv}\right)=1.8 \mu \mathrm{g} / \mathrm{mL}$

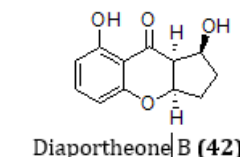

Diaportheone|B (42)

$\mathrm{MIC}_{90}\left(\mathrm{Mtb} \mathrm{H}_{37} \mathrm{Rv}\right)=10 \mu \mathrm{g} / \mathrm{mL}$

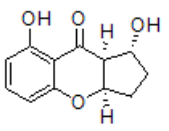

43

$\mathrm{MIC}_{90}\left(\mathrm{Mtb} \mathrm{H}_{37} \mathrm{Rv}\right)=12.5 \mu \mathrm{g} / \mathrm{mL}$

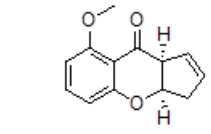

44

$\mathrm{MIC}_{90}\left(\mathrm{Mtb} \mathrm{H}_{37} \mathrm{Rv}\right)=6.25 \mu \mathrm{g} / \mathrm{mL}$

Figure 14: Structures of benzopyran-4-ones and Diaportheone B analogs.

\section{Benzopyran-based natural products as anti-TB agents}

More than half of the current drugs in use comprise of naturally occurring compounds and their derivatives. Natural products have also inspired scientists to synthesize about half of the synthetically produced medicinal compounds. Statistically, 90000 known naturally occurring compounds contribute about $40 \%$ of bioactive new chemical entities [81]. Even though plant species have continually demonstrated that they are a rich source of novel bioactive compounds, only a few species have been extensively investigated for their medicinal properties [82]. Hence, the search for bioactive metabolites has been rejuvenated in recent years. Benzopyrans and their benzo-fused derivatives are widely distributed in nature and are isolated from various medicinal plants [83]. Their occurrence has been partly attributed to numerous prenylation and cyclization reactions in many polyketide biosynthesis pathways [23]. The 2,2-dimethylbenzopyran system is popular in many naturally occurring benzopyrans and exhibits a variety of biological properties [84]. In this section, we discuss natural product extracts bearing the benzopyran scaffold as antiTB agents.

Gupta et al. [85] observed the antimycobacterial activity of Glycyrrhiza glabra root ethanolic extract to be $500 \mu \mathrm{g} / \mathrm{mL}$ against 
Mtb $\mathrm{H}_{37} \mathrm{Ra}$ and $\mathrm{H}_{37} \mathrm{Rv}$ strains through BACTEC assay. Bioactivity guided phytochemical analysis of the roots resulted in the identification of glabridin (45) as the active constituent against $M t b$. The antitubercular activity of glabridin was found to be MIC $=29.16 \mu \mathrm{g} / \mathrm{mL}$ against both strains of $M t b$. Kuete et al. [86] isolated 5 polyphenols from twigs of Dorstenia barteri and screened them for antimycobacterial activity against M. Smegmatis and Mtb $\mathrm{H}_{37} \mathrm{Rv}$ strains. Among the polyphenols, 4-hydroxylonchocarpin (46) exhibited pronounced antimycobacterial activity (MIC=9.76 $\mu \mathrm{g}$ / $\mathrm{mL}$ ) against both mycobacterial strains.

Lall et al. [87] isolated 3 compounds from Helichrysum melanacme and investigated their antitubercular potential against the drug-sensitive strain of M. tuberculosis $\mathrm{H}_{37} \mathrm{Rv}$. Chalcone (47) was the most active compound with an MIC value of $50 \mu \mathrm{g} / \mathrm{mL}$. Chiang et al. [88] isolated 19 compounds from the whole plant of Fatoua pilosa. The antimycobacterial activity of 13 compounds were tested in vitro against $M t b \mathrm{H}_{37} \mathrm{Rv}$ using the Middlebrook-7H10 agar method to determine the MIC values [89]. Benzopyran (48) exhibited the strongest antimycobacterial activity (MIC=30 $\mu \mathrm{g}$ / $\mathrm{mL}$ ) against $M t b \mathrm{H}_{37} \mathrm{Rv}$ in vitro. Wu et al. [90] isolated pisonin B (49) and a plethora of other compounds from the methanol extract of the combined stem and root of Pisonia aculeate shrub. The in vitro antitubercular activity of each compound was evaluated using the $M t b$ strain $\mathrm{H}_{37} \mathrm{Rv}$. Pisonin B was among the most active isolates with an MIC value of $25 \mu \mathrm{g} / \mathrm{mL}$.

Tuntiwachwuttikul et al. [91] isolated four new chromones, perforamone A, B, C, and D together with six known compounds, peucenin-7-methyl ether, 0-methylalloptaeroxylin, perforatic acid, eugenin, saikochromone A and greveichromenol, from the branches of Harrisonia perforata. The antimycobacterial activity of the isolates was assessed against $M t b \mathrm{H}_{37} \mathrm{Ra}$ using the MABA method. Perforamone D (50) was the most active isolate (MIC $=25 \mu \mathrm{g} / \mathrm{mL}$ ). Namdaung et al. [92] isolated six, structurally diverse phenolic compounds and screened them for their antimycobacterial activity against $M t b \mathrm{H}_{37} \mathrm{Ra}$. All compounds showed antitubercular activity, with compound 51 being the most active compound $(\mathrm{MIC}=6.25 \mu \mathrm{g} / \mathrm{mL})$. Other prenylated bioactive natural products were isolated from the fruit hulls of Garcinia mangostana [93]. Among these, Garcinone B (52) was the most active isolate against $M t b \mathrm{H}_{37}$ Ra (Figure 15). Joycharat et al. [94] isolated 11 compounds from the leaves of Aglaia forbesii. The benzopyran flavagline (53) exhibited the highest activity against $M t b \mathrm{H}_{37} \mathrm{Ra}$ with an MIC value of $25 \mu \mathrm{g} / \mathrm{mL}$.

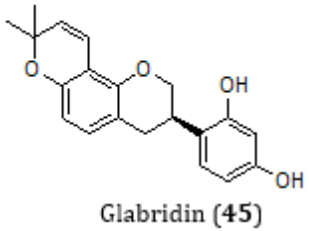

MIC (Mtb $\left.\mathrm{H}_{37} \mathrm{Rv}\right)=29.16 \mu \mathrm{g} / \mathrm{mL}$ MIC $\left(\right.$ Mtb $\left.\mathrm{H}_{37} \mathrm{Ra}\right)=29.16 \mu \mathrm{g} / \mathrm{mL}$<smiles>CC(C)=CCc1c(O)ccc(C(=O)C=Cc2cc(O)c3c(c2)C=CC(C)(C)O3)c1O</smiles>

$\operatorname{MIC}\left(\mathrm{Mtb} \mathrm{H}_{37} \mathrm{Rv}\right)=30 \mu \mathrm{g} / \mathrm{mL}$

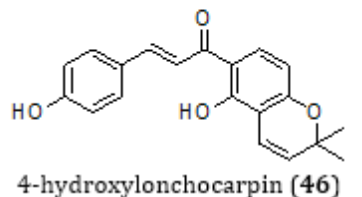

MIC $\left(\right.$ Mtb $\left.\mathrm{H}_{37} \mathrm{Rv}\right)=9.76 \mu \mathrm{g} / \mathrm{mL}$ MIC (M. smegmatis) $=9.76 \mu \mathrm{g} / \mathrm{mL}$<smiles>COc1c(O)cc2oc(C)cc(=O)c2c1O</smiles>

Pisonin B (49)

MIC $\left(\mathrm{Mtb} \mathrm{H}_{37} \mathrm{Rv}\right)=25 \mu \mathrm{g} / \mathrm{mL}$

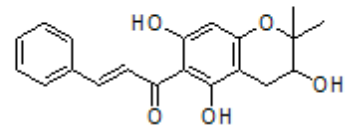

47

MIC (Mtb $\left.\mathrm{H}_{37} \mathrm{Rv}\right)=50 \mu \mathrm{g} / \mathrm{mL}$

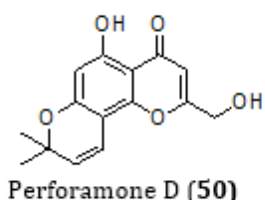

Perforamone D (50)

MIC (Mtb $\left.\mathrm{H}_{37} \mathrm{Rv}\right)=25 \mu \mathrm{g} / \mathrm{mL}$

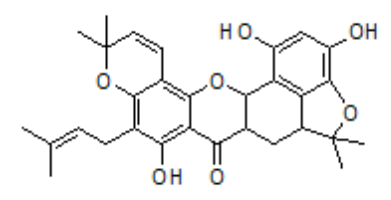

51<smiles>CC(C)=CCc1c(O)cc2oc3cc(O)c4c(c3c(=O)c2c1O)CCC(C)(C)O4</smiles>

Garcinone B (52)

$\operatorname{MIC}\left(\right.$ Mtb $\left.\mathrm{H}_{37} \mathrm{Ra}\right)=6.25 \mu \mathrm{g} / \mathrm{mL} \quad$ MIC $\left(\right.$ Mtb $\left.\mathrm{H}_{37} \mathrm{Ra}\right)=6.25 \mu \mathrm{g} / \mathrm{mL}$

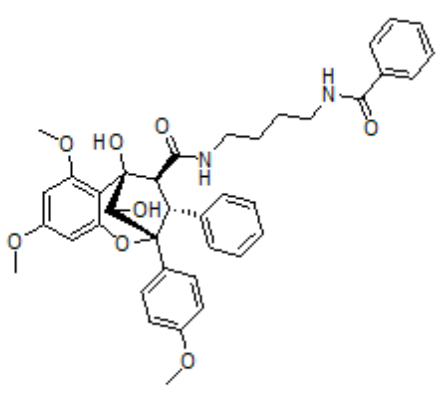

53

$\operatorname{MIC}\left(\right.$ Mtb $\left.\mathrm{H}_{37} \mathrm{Ra}\right)=25 \mu \mathrm{g} / \mathrm{mL}$

Figure 15: Structures of benzopyran-based natural products as anti-TB agents (45-53). 
In conclusion, benzopyrans isolated from natural products are a significant class of antitubercular agents. Moreover, the target identification and mode of action studies on these phytochemicals may lead to identification of novel targets for further drug discovery work and synthetic modifications of these compounds could result into more potent compounds and lead drug candidates.

\section{Benzopyran: Structural requirements for anti-TB activity}

From the published data, it is evident that the benzopyran nucleus substituted at all positions (except position 1) with varied substituents produced potent anti-TB candidates. All the positions tolerated no substitution or substitution with differing substituents. At the $2^{\text {nd }}$ position of the benzopyran, substituents may vary from amines, methyl and spirocycloalkyls. Among them the 2,2-dimethyl and spirocycloalkyl substituted derivatives demonstrated excellent anti-TB activity. The $3^{\text {rd }}$ position may be substituted with phenyl and heterocyclic rings. Amides and heterocyclic rings at the 3rd position enhance anti-TB activity. The 4 th position can be substituted with carbonyl and hydroxyl groups as well as phosphonates and heterocycles. Benzopyrans with carbonyl group at the 4 th position were potent against Mtb. The phenyl ring of the benzopyran could either be substituted or fused with aromatic and heterocyclic rings such as furan and pyridine. Generally, the fused derivatives demonstrated improved antitubercular activity. Benzopyran with a methyl group at the 5 th position evinced better activity, consistent with other methyl substitutions at position 6, 7 and 8. Other functional group substitutions in the phenyl ring that lead to improved anti-TB activity include halogens, alkyl ethers, triflouromethyl, hydroxyl, nitro group and phenyl ring. Reducing the double bond of the pyran ring generally leads to loss of activity (Figure 16).

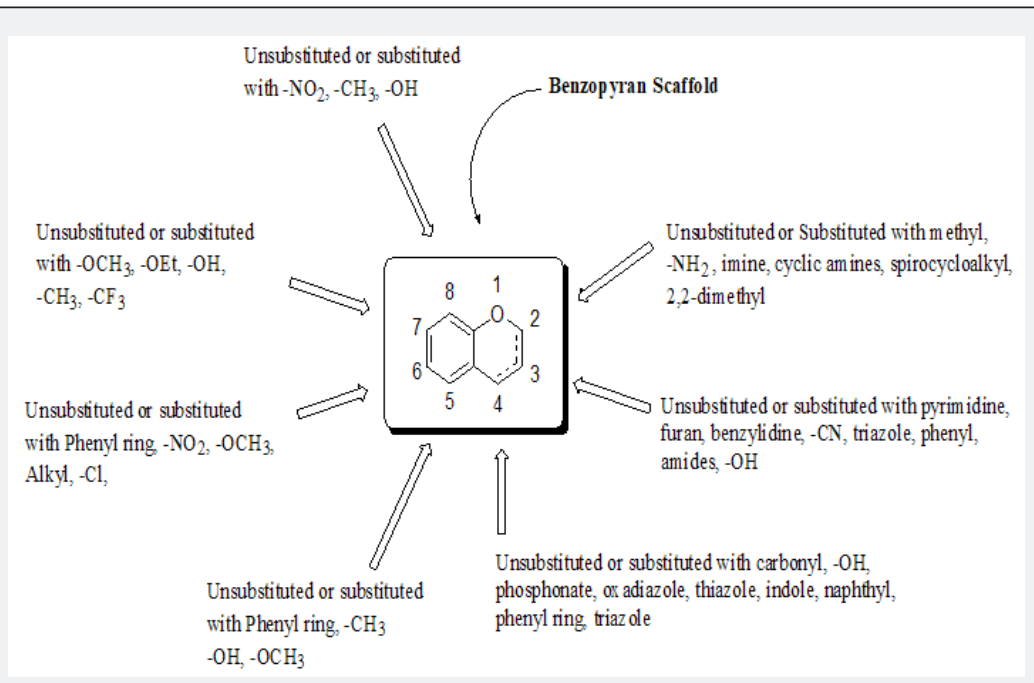

Figure 16: Structural requirements around benzopyran nucleus for anti-TB activity.

\section{Efforts towards target identification}

An increase in efforts to discover antitubercular therapeutics has brought insights into the biology of Mycobacterium tuberculosis. Promising new drugs such as bedaquiline, which inhibits ATP synthase [95], and the nitroimidazoles delamanid and pretomanid, which inhibit both mycolic acid synthesis and energy production [96] have brought hope in the discovery of new drugs with novel mechanisms of action, capable of inhibiting multi- and extensively drug -resistant $M t b$ and, potentially nonreplicating $M t b$ with the hope of shortening the therapy duration. Although, not enough progress on investigating the mechanism action of benzopyrans, similar compounds such as coumarins have been reported to inhibit the fatty acyl-AMP ligase essential for mycobacterial growth, FadD32 [97]. Benzothiazinethiones, (delivered a preclinical candidate, SKLB-TB1001) from which some benzopyrans were derived from through scaffold morphing have been reported to be decaprenylphosphoryl- $\beta$-D-ribose 2'-epimerase (DprE1) inhibitors [98]. Similarly, flavonoids which are structurally like Pisonin B (49) are known to inhibit the $\beta$-hydroxyacyl-ACP dehydratase (HadAB) complex [99]. These new targets provide an avenue for exploration away from the known mechanisms of action of the standard drugs in the market.

\section{Conclusion and future aspects}

TB is still the leading cause of death from a single infectious agent, ahead of HIV/AIDS. With an estimated 1 million children developing TB in 2017, there is no doubt this statistic provokes the global scientific community to treat this deadly disease. However, current control strategies have little impact on TB control and some M. tuberculosis strains are resistant to all existing medication used for the treatment of TB, highlighting the need for new drugs with novel modes of action. The new drug should have increased capacity to inhibit bacterial growth and shorten treatment time, new mechanism of action, be less toxic and cheap to make so that it can be easily accessible to the developing world. Benzopyrans and its derivatives are ubiquitous natural products 
and have displayed a broad spectrum of pharmaceutical activities. Current literature clearly depicts substituted benzopyrans to play a vital role in the development of new anti-TB chemotypes. Multiple authors have reported benzopyran-anchored derivatives as potent antitubercular agents. This review has provided collective information on various benzopyran-based compounds with antitubercular activity that will be useful to initiate further drug discovery efforts using these benzopyran derivatives as a starting point to develop potent anti-TB agents. The identification of biological targets and mode of action of most reported active compounds has not been fully explored. This area together with SAR-based study will play an important role in guiding researchers to design safe and potent benzopyran drugs for TB treatment.

\section{Acknowledgement}

The authors would like to thank Sandeep Ghorpade for proofreading the article.

\section{Funding}

This research did not receive any specific grant from funding agencies in the public, commercial, or not-for-profit sectors. However, the authors would like to thank their respective employers which are; University of Eswatini, University of Johannesburg and University of Zimbabwe.

\section{References}

1. Sandhu G (2011) Tuberculosis: Current situation, challenges, and overview of its control programs in India. J Global Infect Dis 3(2): 143150.

2. Grange JM (2009) The genus Mycobacterium and the Mycobacterium tuberculosis complex," in Tuberculosis: A Comprehensive Clinical Reference. ( $\left.1^{\text {st }}\right)$ Ed, Saunders, Philadelphia, PA, USA, pp 44-59.

3. Alexander KA, Laver PN, Michel AL, Williams M, van Helden PD, et al. (2010) Novel Mycobacterium tuberculosis Complex Pathogen, M. mungi. Emerg Infect Dis 16(8): 1296-1299.

4. Munch R (2003) On the shoulders of giants, Robert Koch. Microb Infect 5(1): 69-74

5. World health organization (2018) Global tuberculosis report.

6. Koul A, Arnoult E, Lounis N, Guillemont J, Andries K (2011) The challenge of new drug discovery for tuberculosis. Nature 469 (7331): 483-490.

7. World health organization (2010) Guidelines for Treatment of tuberculosis.

8. Ma Z, Lienhardt C, McIlleron H, Nunn AJ, Wang X (2010) Global tuberculosis drug development pipeline: the need and the reality. Lancet 375(9731): 2100-2109.

9. Olaru ID, Lange C, Heyckendorf J (2015) Personalized medicine for patients with MDR-TB. J Antimicrob Chemother 71(4): 852-855.

10. Nardell EA (2015) Transmission and Institutional Infection Control of Tuberculosis. Cold Spring Harb Perspect Med 6(2): 1-12.

11. Golden MP, Vikram HR (2005) Extrapulmonary tuberculosis: an overview. Am Fam Physician 72(9): 1761-1768.

12. Ayed HB, Koubaa M, Marrakchi C, Rekik K, Hammami F, et al. (2018) Extrapulmonary Tuberculosis: Update on the Epidemiology, Risk Factors and Prevention Strategies. Int J Trop Dis 1(1): 1-6.
13. World health organization (2007) Tuberculosis: WHO fact sheet no. 104.

14. Stop TB Patnership (2015) High Burden Countries.

15. Umesiri FE, Sanki AK, Boucau J, Ronning DR, Sucheck SJ (2010) Recent advances toward the inhibition of $\mathrm{MAG}$ and LAM synthesis in Mycobacterium tuberculosis. Med Res Rev 30(30): 290-326.

16. Tripathi RP, Tewari N, Dwivedi N, Tiwari VK (2005) Fighting tuberculosis: An old disease with new challenges. Med Res Rev 25(1): 93-131.

17. Quan D, Nagalingam G, Payne R, Triccas JA (2017) New tuberculosis drug leads from naturally occurring compounds. Int J Infect Dis 56: 212-220.

18. Almeida Da Silva PE, Palomino JC (2011) Molecular basis and mechanisms of drug resistance in Mycobacterium tuberculosis: classical and new drugs. J Antimicrob Chemother 66(7): 1417-1430.

19. Keri RS, Rajappa CK, Patil SA, Nagaraja BM (2016) Benzimidazole-core as an antimycobacterial agent. Pharmacol Rep 68(6): 1254-1265.

20. Gomtsyan A (2012) Heterocycles in drugs and drug discovery. Chem Heterocycl Compd 48(1): 7-10.

21. Xiu C, Hua Z, Xiao BS, Tang WJ, Zhou HP, et al. (2017) Novel benzopyran derivatives and their therapeutic applications: a patent review (20092016). Expert Opin Ther Pat 27(9): 1031-1045.

22. Ellis GP (1977) The Chemistry of Heterocyclic Compounds: Chromenes, Chromanones, and Chromones. John Wiley, New York, NY, USA.

23. Nicolaou KC, Pfefferkorn JA, Roecker AJ, Cao G Q Barluenga S, et al. (2000) Natural Product-like Combinatorial Libraries Based on Privileged Structures. 1. General Principles and Solid-Phase Synthesis of Benzopyrans. J Am Chem Soc 122(41): 9939-9953.

24. Piyush K, Kuldeep S, Azizur RM, Misbahul HS, Pranay W (2018) A review of benzopyran derivatives in pharmacotherapy of breast cancer. Asian J Pharm Clin Res 11(7): 43-46.

25. Zhang Y (2013) Deuterated benzopyran compounds and application thereof. WO 2013189121.

26. Gillessen D, Jäger J (2009) Aqueous pharmaceutical formulation. WO 2009124586.

27. Giordani A (2009) 2-aryl and 2-heteroaryl 4H-1-Benzopyran-4-one-6amidino derivatives for the treatment of arthritis, cancer and related pain. WO 2009109230.

28. Wang Y (2013) Benzopyran compounds, preparation method and applications thereof.

29. Kong L (2017) 4-hydroxy coumarin-3 Schiff bases derivatives and their use in the treatment of Alzheimer's disease. CN105017195B.

30. Ravaux MR (2013) Use of coumarin derivatives for the preparation of drugs for treating skin diseases. WO 2013010963.

31. Josep RP (2013) Pyrano[3,2-c] benzopyran-6(2H)-one derivatives and uses thereof. WO 2013045495.

32. Anthony KG, Strych U, Yeung KR, Shoen CS, Perez O, et al. (2011) New Classes of Alanine Racemase Inhibitors Identified by High-Throughput Screening Show Antimicrobial Activity against Mycobacterium tuberculosis. PLoS ONE 6(5): 1-9.

33. Everett ST (2010) Treatment or prophylaxis of proliferative conditions. WO 2010125350.

34. Mereddy VR (2013) Therapeutic compounds. WO 2013109972.

35. Shengbiao W (2011) Benzopyranyl-3-alcohol esterified derivative serving as antineoplastic multidrug resistance inhibitor and preparation method and application of benzopyranyl-3-alcohol esterified derivative. CN102153535A 
36. Shaojie W (2012) 2H-1-benzopyran-2-one compounds with alphaglucosidase inhibitory activity and medicinal composition of $2 \mathrm{H}-1$ benzopyran-2-one compounds. CN102718757B.

37. Keri RS, Sasidhar BS, Nagaraja BM, Santos MA (2015) Recent progress in the drug development of coumarin derivatives as potent antituberculosis agents. Eur J Med Chem 100: 257-269.

38. Askun T (2015) The significance of flavonoids as potential antituberculosis compounds. Research \& Reviews: J Pharm Toxicolo Stud. 3(3): 1-11.

39. Raju CB, Nageswara R, Suman P, Yogeeswari P, Sriram D, et al. (2011) Synthesis, structure-activity relationship of novel substituted 4H-chromen-1,2,3,4-tetrahydropyrimidine-5-carboxylates as potential anti-mycobacterial and anticancer agents. Bioorg Med Chem Lett 21(10): 2855-2859.

40. Golus J, Sawicki R, Widelski J, Ginalska G (2016) The agar microdilution method - a new method for antimicrobial susceptibility testing for essential oils and plant extracts. J Appl Microbiol 121(5): 1291-1299.

41. Mujahid M, Gonnade RG, Yogeeswari P, Sriram D, Muthukrishnan M (2013) Synthesis and antitubercular activity of amino alcohol fused spirochromone conjugates. Bioorg Med Chem Lett 23(5): 1416-1419.

42. Dongamanti A, Aamate VK, Devulapally MG, Gundu S, Balabadra S, et al. (2017). Bis-spirochromanones as potent inhibitors of Mycobacterium tuberculosis: Synthesis and biological evaluation. Mol Divers 21(4): 999-1010.

43. Kabbe H J, Widdig A (1982) Synthesis and Reactions of 4-Chromanones. Angew Chem Int Ed Engl 21(4): 247-256

44. Singh A, Bimal D, Kumar R, Maikhuri VK, Thirumal M, et al. (2018) Synthesis and antitubercular activity evaluation of 4-furano-coumarins and 3-furano-chromones. Synth Commun 48(18): 2339-2346.

45. Mendoza Aguilar M, Almaguer Villagrán L, Arce Paredes P, Cid Gutiérrez JL, Rojas Espinosa O, et al. (2012) The use of the microplate alamar blue assay (MABA) to assess the susceptibility of Mycobacterium lepraemurium to anti-leprosy and other drugs. J Infect Chemother 18(5): 652-661.

46. Das U, Lorand T, Dimmock SG, Perjesi P, Dimmock JR (2014) 3-Benzylidene-4-chromanones: a novel cluster of anti-tubercular agents. J Enzyme Inhib Med Chem 30(2): 259-263.

47. Lee RE, Hurdle JG, Liu J, Bruhn DF, Matt T, et al. (2014) Spectinamides: a new class of semisynthetic antituberculosis agents that overcome native drug efflux. Nat Med 20(2): 152-158.

48. Feng L, Maddox MM, Alam MZ, Tsutsumi LS, Narula G, et al. (2014) Synthesis, structure-activity relationship studies, and antibacterial evaluation of 4-chromanones and chalcones, as well as olympicin A and derivatives. J Med Chem 57(20): 8398-8420.

49. Sriram D, Yogeeswari P, Dinakaran M, Banerjee D, Bhat P, et al. (2010) Discovery of novel antitubercular 2,10-dihydro-4aH-chromeno[3,2-c] pyridin-3-yl derivatives. Eur J Med Chem 45(1): 120-123.

50. Nalla V, Shaikh A, Bapat S, Vyas R, Karthikeyan M, et al. (2018) Identification of potent chromone embedded [1,2,3]-triazoles as novel anti-tubercular agents. R Soc Open Sci 5(4): 171750-171764.

51. Khan GA, Naikoo GA, War JA, Pandit UJ, Sheikh MUD, et al. (2018) Synthesis, Antitubercular Activity and DNA-binding Study of some 2-Amino-3-cyano-4H-chromen-4-ylphosphonates. Der Pharma Chemica 10(2): 118-127.

52. Drew WL, Barry AL, O’Toole R, Sherris JC (1972) Reliability of the Kirby-Bauer disc diffusion method for detecting methicillin-resistant strains of Staphylococcus aureus. Appl Microbiol 24(2): 240-247.

53. Laxmi VS, Reddy TY, Kuarm BS, Reddy NP, Crooks PA, et al.
(2011) Synthesis and evaluation of chromenyl barbiturates and thiobarbiturates as potential antitubercular agents. Bio org Med Chem Lett 21(14): 4329-4331.

54. Tantry SJ, Degiacomi G, Sharma S, Jena LK, Narayan A, et al. (2015) Whole cell screen-based identification of spiropiperidines with potent antitubercular properties. Bioorg Med Chem Lett 25(16): 3234-3245.

55. Khan GA, Naikoo GA, War JA, Sheikh IA, Pandit UJ, et al. (2018) An Efficient Green Synthesis of Some Functionalized Spiro Chromene Based Scaffolds as Potential Antitubercular Agents. J Heterocycl Chem 55(3): 699-708.

56. Warekar PP, Patil PT, Patil KT, Jamale DK, Kolekar GB, et al. (2017) PTSA-catalyzed straightforward novel approach for the synthesis of 1,2-bis(4-nitrophenyl)-1H-benzo[f]chromen-3-amine and the evaluation of their antituberculosis activity. Res Chem Intermed 43(7): 4115-4127.

57. Angelova VT, Valcheva V, Vassilev NG, Buyukliev R, Momekov G, et al. (2017) Antimycobacterial activity of novel hydrazide-hydrazone derivatives with $2 \mathrm{H}$-chromene and coumarin scaffold. Bioorg Med Chem Lett 27(2): 223-227.

58. Canetti G, Fox W, Khomenko A, Mahler HT, Menon NK, et al. (1969) Advances in techniques of testing mycobacterial drug sensitivity, and the use of sensitivity tests in tuberculosis control programs. Bull World Health Organ 41(1): 21-43.

59. Tripathi RP, Bisht SS, Pandey VP, Pandey SK, Singh S, et al. (2010) Search of antimycobacterial activities in hybrid molecules with benzopyran skeleton. Med Chem Res 20(9): 1515-1522.

60. Prado S, Ledeit H, Michel S, Koch M, Darbord JC, et al. (2006) Benzofuro[3,2-f][1] benzopyrans: A new class of antitubercular agents. Bioorg Med Chem 14(15): 5423-5428.

61. Prado S, Janin YL, Saint Joanis B, Brodin P, Michel S, et al. (2007) Synthesis and antimycobacterial evaluation of benzofurobenzopyran analogues. Bioorg Med Chem 15(5): 2177-2186.

62. Palomino J C, Martin A, Camacho M, Guerra H, Swings J, et al. (2002) Resazurin Microtiter Assay Plate: Simple and Inexpensive Method for Detection of Drug Resistance in Mycobacterium tuberculosis. Antimicrob Agents Chemother 46(8): 2720-2722.

63. Alvey L, Prado S, Huteau V, Saint Joanis B, Michel S, et al. (2008) A new synthetic access to furo[3,2-f]chromene analogues of an antimycobacterial. Bioorg Med Chem 16(17): 8264-8272.

64. Termentzi A, Khouri I, Gaslonde T, Prado S, Saint Joanis B, et al. (2010) Synthesis, biological activity, and evaluation of the mode of action of novel antitubercular benzofurobenzopyrans substituted on A ring. Eur J Med Chem 45(12): 5833-5847.

65. Ganihigama DU, Sureram S, Sangher S, Hongmanee P, Aree T, et al. (2015) Antimycobacterial activity of natural products and synthetic agents: Pyrrolodiquinolines and vermelhotin as anti-tubercular leads against clinical multidrug resistant isolates of Mycobacterium tuberculosis. Eur J Med Chem 89: 1-12.

66. Kamdar NR, Haveliwala DD, Mistry PT, Patel SK (2010) Design, synthesis and in vitro evaluation of antitubercular and antimicrobial activity of some novel pyranopyrimidines. Eur J Med Chem 45(11): 5056-5063.

67. Kamdar NR, Haveliwala DD, Mistry PT, Patel SK (2011) Synthesis and evaluation of in vitro antitubercular activity and antimicrobial activity of some novel $4 \mathrm{H}$-chromeno[2,3-d]pyrimidine via 2-amino-4-phenyl4H-chromene-3-carbonitriles. Med Chem Res 20(7): 854-864.

68. Haveliwala DD, Kamdar NR, Mistry PT, Patel SK (2014) ChromoneFused Cytosine Analogues: Synthesis, Biological Activity, and Structure-Activity Relationship. Nucleosides, Nucleotides and Nucleic Acids 33(2): 80-91. 
69. Haveliwala DD, Kamdar NR, Mistry PT, Patel SK (2011) Synthesis of novel thiopyrimidines: an investigation of anti-tubercular and antimicrobial activity. J Sulfur Chem 32(5): 451-462.

70. Haveliwala DD, Kamdar NR, Mistry PT, Patel SK (2013) Synthesis of functionalized H-[1]Benzopyrano[2,3-b]pyridines by the Friedländer approach: antimycobacterial and antimicrobial profile. Helv Chim Acta 96(5): 897-905.

71. Balasubramanian DB, Muthusaravanan S, Choon TS, Ashraf AM, Perumal S (2014) Sequential synthesis of amino-1,4-naphthoquinoneappended triazoles and triazole-chromene hybrids and their antimycobacterial evaluation. Eur J Med Chem 85: 737-746.

72. Khare SP, Deshmukh TR, Sangshetti JN, Krishna VS, Sriram D, et al. (2018) Design, Synthesis and Molecular Docking Studies of Novel Triazole-Chromene Conjugates as Antitubercular, Antioxidant and Antifungal Agents. Chemistry Select 3(46): 13113-13122.

73. Ashok D, Chiranjeevi P, Kumar AV, Sarasija M, Krishna VS, et al. (2018) 1,2,3-Triazole-fused spirochromenes as potential anti-tubercular agents: synthesis and biological evaluation. RSC Adv 8(30): 1699717007.

74. Muthukrishnan M, Mujahid M, Yogeeswari P, Sriram D (2011) Syntheses and biological evaluation of new triazole-spirochromone conjugates as inhibitors of Mycobacterium tuberculosis. Tetrahedron Lett 52(18) 2387-2389.

75. Alvey L, Prado S, Saint Joanis B, Michel S, Koch M, et al. (2009) Diversityoriented synthesis of furo[3,2-f]chromanes with antimycobacterial activity. Eur J Med Chem 44(6): 2497-2505.

76. Li P, Wang B, Zhang X, Batt SM, Besra GS, et al. (2018) Identification of novel benzothiopyranone compounds against mycobacterium tuberculosis through scaffold morphing from benzothiazinones. Eur J Med Chem 160: 157-170.

77. Chatterjee A (2014) Compounds for treatment of drug resistant and persistent tuberculosis. WO 2014190199.

78. Ananthan S, Faaleolea ER, Goldman RC, Hobrath JV, Kwong CD, et al. (2009) High Throughput Screening for Inhibitors of Mycobacterium tuberculosis H37Rv. Tuberculosis (Edinb) 89(5): 334-353.

79. Swaroop SP, Raut GN, Gonnade RG, Verma P, Gokhale RS et.al (2012) Antituberculosis agent diaportheone B: synthesis, absolute configuration assignment, and anti-TB activity of its analogues. Org Biomol Chem 10(28): 5385-5394.

80. Bungihan ME, Tan MA, Kitajima M, Kogure N, Franzblau SG, et al. (2011) Bioactive metabolites of Diaporthe sp. P133, an endophytic fungus isolated from Pandanus amaryllifolius. J Nat Med 65: 606-609.

81. Dar RA, Shahnawaz M, Rasool S, Qazi PH (2016) Natural product medicines: A literature update. J Phytopharmacol 6(6): 340-342.

82. Heinrich M, Gibbons S (2001) Ethnopharmacology in drug discovery: an analysis of its role and potential contribution. J Pharma Pharmac 53: 425-432.

83. Pratap R, Ram VJ (2014) Natural and Synthetic Chromenes, Fused Chromenes, and Versatility of Dihydrobenzo[h]chromenes in Organic Synthesis. Chem Rev 114(20): 10476-10526.

84. Narender T, Gupta S, Gupta S (2004) A convenient and biogenetic type synthesis of few naturally occurring chromeno dihydrochalcones and their in vitro antileishmanial activity. Bio org Med Chem Lett 14(15): 3913-3916.

85. Gupta VK, Fatima A, Faridi U, Negi AS, Shanker K, et al. (2008) Antimicrobial potential of Glycyrrhiza glabra roots. J Ethnopharmacol 116(2): 377-380.

86. Kuete V, Ngameni B, Mbaveng AT, Ngadjui B, Meyer JJM, et al. (2010) Evaluation of flavonoids from Dorstenia barteri for their antimycobacterial, antigonorrheal and anti-reverse transcriptase activities. Acta Trop 116(1): 100-104.

87. Lall N, Hussein AA, Meyer JJM (2006) Antiviral and antituberculous activity of Helichrysum melanacme constituents. Fitoterapia 77(3): 230-232.

88. Chiang C C, Cheng M J, Peng C F, Huang H Y, Chen I S (2010) A novel dimeric coumarin analog and antimycobacterial constituents from Fatoua pilosa. Chem Biodivers 7(7): 1728-1736.

89. Limb DI, Wheat PF, Spencer RC, Harris GS, Rayner AB, et al. (1993) Comparison of techniques for antimicrobial susceptibility testing of mycobacteria. J Clin Pathol 46(5): 403-407.

90. Wu M C, Peng C F, Chen I S, Tsai I L (2011) Antitubercular chromones and flavonoids from Pisonia aculeata. J Nat Prod 74(5): 976-982.

91. Tuntiwachwuttikul P, Phansa P, Pootaeng On Y, Taylor WC (2006) Chromones from the branches of Harrisonia perforate. Chem Pharm Bull (Tokyo) 54(1): 44-47.

92. Namdaung U, Aroonrerk N, Suksamrarn S, Danwisetkanjana K, Saenboonrueng J, et al. (2006) Bioactive constituents of the root bark of Artocarpus rigidus subsp. ridigus. Chem Pharm Bull (Tokyo) 54(10): 1433-1436.

93. Skusamrarn S, Suwannapoch N, Phakhodee W, Thanuhiranlert J, Ratananukul P, et al. (2003) Antimycobacterial activity of prenylated xanthones from the fruits of Garcinia mangostana. Chem Pharm Bull (Tokyo) 51(7): 857-859.

94. Joycharat N, Greger H, Hofer O, Saifah E (2008) Flavaglines and triterpenoids from the leaves of Aglaia forbesii. Phytochemistry 69(1): 206-211.

95. Nagabushan H, Roopadevi H S (2014) Bedaquiline: A novel antitubercular drug for multidrug-resistant tuberculosis. J Postgrad Med 60(3): 300-302.

96. Manjunatha U, Boshoff HIM, Barry CE (2009) The mechanism of action of PA-824. Commun Integr Biol 2(3): 215-218.

97. Kawate T, Iwase N, Shimizu M, Stanley SA, Wellington S, et al. (2013) Synthesis and structure-activity relationships of phenyl-substituted coumarins with anti-tubercular activity that target FadD32. Bio org Med Chem Lett 23(22): 6052-6059.

98. Gao C, Peng C, Shi Y, You X, Ran K, et.al. (2016) Benzothiazinethione is a potent preclinical candidate for the treatment of drug-resistant tuberculosis. Sci Rep 6(1): 1-9.

99. Brown AK, Papaemmanouil A, Bhowruth V, Bhatt A, Dover LG, et al. (2007) Flavonoid inhibitors as novel antimycobacterial agents targeting Rv0636, a putative dehydratase enzyme involved in Mycobacterium tuberculosis fatty acid synthase II. Microbiology 153(10): 3314-3322. 
(C) This work is licensed under Creative

DOI: $10.19080 / O M C I J .2020 .10 .555784$
Your next submission with Juniper Publishers will reach you the below assets

- Quality Editorial service

- Swift Peer Review

- Reprints availability

- E-prints Service

- Manuscript Podcast for convenient understanding

- Global attai nment for your research

- Manuscript accessibility in different formats

(Pdf, E-pub, Full Text, Audio)

- Unceasing customer service

Track the below URL for one-step submission https://juniperpublishers.com/online-submission.php 